\title{
On the Career and the Cognition of Yogins ${ }^{1}$
}

In the present paper, I shall first attempt to reconstruct Dharmakīrti's notion of a yogin's career on the basis of the statements one can find scattered throughout his very influential Pramānavārttika. I shall try to draw a coherent picture of both yoga and yogins, from the first insights ( $\operatorname{praj} \tilde{n} \bar{a})$ that take place when still in the stage of an "ordinary person" (prthagjana), who is beset by a false view of self (satkāyadrsți), to the culmination of the yogic endeavour at emancipation (mukti) and/or enli-

1 The present paper is the fifth in a series of studies of Dharmakīrti's religious philosophy, see Eltschinger 2005a and b, 2007 and forthcoming. Most sincere thanks are due to Prof. Ernst Steinkellner, Prof. John Taber and Dr. Helmut Krasser, who carefully read through the present paper, and to Mrs Cynthia Peck-Kubacek, who very kindly improved my English. Though I could not do justice to all his suggestions and remarks, I am much indebted to Prof. Eli Franco's very insightful comments on this paper. Since the present study was written in 2005, it did not take into consideration John Dunne's 2006 essay on the yogins' cognition. Dunne's exegetical hypothesis is, however, diametrically opposed to mine. To put it in a nutshell, Dunne argues that "Dharmakīrti does not choose to present yogic perception as a mystical gnosis that encounters or uncovers real things in the world" (Dunne 2006: 500 ), or, to put it in other words, that "Dharmakīrti deliberately chooses to downplay the notion that, through spiritual exercises, an adept gains extraordinary sensory abilities" (Dunne 2006: 504). As I shall try to argue in the second part of this paper, I think that Dharmakīrti actually did hold the opinion that, at the completion of the path, the yogin has a direct perceptual encounter with reality itself. In my opinion, Dharmakīrti inherits from ideas that can be found, e.g., in the Śrāvakabhümi, and which have been summarized recently by Lambert Schmithausen. According to the latter (Schmithausen 2007: 232/79), "the contemplation process culminates in a non-conceptualizing (nirvikalpa) perceptual cognition or insight (pratyakșam jñanadarśanam) that transcends the mental image and directly apprehends the respective object itself." To be more precise, the path described in the Śrāvakabhūmi "culminates in a non-conceptualizing (nirvikalpa) perceptual cognition (pratyakșajñāna) of the four Noble Truths" (Schmithausen 2007: 232/79). Research for this article was supported by the Austrian Science Fund in the context of the FWF-Project P19862 ("Philosophische und religiöse Literatur des Buddhismus"). 
ghtenment (bodhi). The description aims at presenting the religious conceptions that form the background of Dharmakirti's epistemological account of a yogin's perception (yogipratyaksa). In the second part of this paper, I shall adduce a new and somewhat provocative hypothesis concerning the still rather unclear subject of the nature of the yogin's cognition. I shall try to show that the properties Dharmakīrti ascribes to a mystic's perception (pratyakșa), viz., vividness (spaștābhatā), nonconceptuality (nirvikalpatā) and reliability (avisamvāditā), should be taken at face value. To put it in other words, I shall attempt to demonstrate why, though of an admittedly much higher type, the yogins' perception of the (Buddhist) truths does not differ from ordinary perception.

\section{THE CAREER OF A YOGIN}

\section{On Ordinary Persons (prthagjana) and Nescience (avidyā)}

1.1. Prthagjanatva. The intrinsically painful and unsatisfactory condition from which a yogin wishes to free himself is traditionally described as the state of an ordinary/worldly person (prthagjanatva). Buddhist definitions of this state are of a mainly negative character: the ordinary person is one in whose psychic stream the path of seeing (darsana$m \bar{a} r g a$ ), the four noble truths (äryasatya) or, to be more precise, the supramundane (lokottara) noble factors (äryadharma), have not yet arisen (see below §3.2). According to the Sautrāntikas, the state of an ordinary person - which is denied any reality as a separate entity ${ }^{2}-$ is to

2 The Vaibhāṣikas, some of whom at least classify prthagjanatva as a factor dissociated from the mind (cittaviprayuktadharma), define prthagjanatva as follows (AKBh 66,9-12 together with AK 2.40bc ${ }_{1}$ ): mārgasyāprāptir isyate | prthagjanatvam | pṛthagjanatvam katamat | āryadharmānāam alābha iti śāstrapāthah $\mid$ alābhaś ca nāma aprāptih |. "[T]he non-possession of the noble path is held to be the nature of an ordinary person (prthagjanatva). As the śāstra states: 'What is the nature of an ordinary person? It is the non-acquisition of the noble factors.' Nonacquisition is a synonym for non-possession." Translation (of Sanghabhadra's Nyāyānusāra 399a) in Cox 1995: 202. According to Cox (1995: 223n. 102), śāstra here refers to Jñānaprasthāna 2, 298c5ff, and Mahāvibhāṣā 45, 232b9ff: "What is the nature of an ordinary person? The nature of an ordinary person is the present, past, and future non-possession of noble factors, noble heat, noble views, noble patience, noble inclination, and noble insight." Translation in Cox 1995: 223n. 102. 
be defined as follows ${ }^{3}$ : "The state of an ordinary person is the stream in which the noble factors have not arisen." Not surprisingly, Vasubandhu's Sautrāntika definition coincides with the one put forth by Yogācāras, who hold the state (gnas skabs = avasthā?) of an ordinary person to be one in which the supramundane (lokottara) noble dharmas have not arisen ( $m a$ bskyed $p a=$ anutpanna?). ${ }^{4}$ Idealist sources moreover regard the state of an ordinary person, which they also consider being besieged with erroneous clinging to (the notion of) person(s) and dharmas (pudgaladharmābhiniveśasammoha), as the obstacle (āvarana) that prevents one from entering the first Bodhisattva stage $(\text { bhümi })^{5}$ Provided the yogin has not, still as an ordinary person, gone through (parts of) the so-called mundane path of cultivation (laukikabhāvanāmārga), his condition is characterized by entanglement in nescience (avidya , or ignorance, ajñanna, delusion, moha) and the depravities, moral faults and defilements (äsrava, doșa, [upa]kleśa, etc.) nescience is responsible for, all of which make one subject to rebirth

See also Siddhi I.57-58. Note that, at least for the epistemologists, the category of arvāgdarśin ("jemand, dessen Erkenntnis von unserer Art ist," Steinkellner 1979: 79n. 258) is wider than the category of prthagjana: whereas the second refers to those who have not yet entered the path of vision/first Bodhisattva stage, the first is often though not systematically used as an equivalent of asarvadarsin ("nonomniscient"), i.e., seems to refer to all persons who are not Buddhas.

${ }^{3}$ AKBh 66,20: anutpannāryadharmasantatih prthagjanatvam |. The Mahāvibhāsāa (45, 231b26-29) ascribes to the Dārștāntikas the conception according to which prthagjanatva is no real entity (Cox 1995: 224n. 109). See also AKVy 154,28-31 on AKBh 66,20: anutpannāryadharmā santatir iti. anutpannā āryadharmā asyām ity anutpannāryadharmā santatih pṛthagjanatvam. anutpannāryamārgā skandhasantatir ity arthah. arthād utpannāryadharmā santatir āryatvam ity uktam bhavaty āśrayaparāvrtteh.

${ }^{4}$ VinSg P77a8, as quoted by Kritzer (2005: 63): so so 'i skye bo gnas skabs gan la gdags $\mid$ rnam pa du yod ce na $\mid$ smras pa | 'jig rten las 'das pa 'phags pa'i chos ma bskyed pa'i gnas skabs la'o\|.

5 According to SNS 9.5.1 (see Lamotte 1935: 240), each stage or bhümi opposes a specific type of error (sammoha), the first opposing pudgaladharmābhiniveśa-

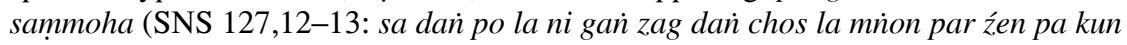
tu rmons pa). According to Vasubandhu's commentary on MS 5.1 (see Lamotte 1973: II.196 as well as II.39*, which contains numerous bibliographical references to prthagjanas), prthagjanatva opposes the first stage. Siddhi II.642 explicitly identifies the SNS's sammoha to Vasubandhu's prthagjanatā, the latter being defined as the (bijjas of the) kleśa ${ }^{\circ}$ and jũeyāvarana of the speculative type (see Siddhi II.639640 as well as II.590). 
(punarjanman) and re-existence (punarbhava), i.e., to the intrinsically painful (duhkha) cycle of transmigration (samsāra) ${ }^{6}$

1.2. Satkāyadrști. Dharmakīrti identifies the traditional Buddhist concept of nescience with the equally traditional concept of false view of self (satkāyadrsți, or ${ }^{\circ}$ darśana), ${ }^{7}$ the latter being in turn equivalent to the belief in a self (atmagraha) or in a (personal) being (sattvagraha). ${ }^{8}$ What does the false view of self consist of? According to Sākyabuddhi and Karnakagomin, satkāyadrști is to be explained as clinging or adherence to the self and one's own (ātmātmīyābhiniveśa), ${ }^{9}$ which is close to the definitions of prthagjanatva provided earlier by the Sautrāntikas as well as the Yogācāras. According to (the Sautrāntika) Vasubandhu, satkāyadrsțti consists in the false view of the self and one's own ( $\bar{a} t m \bar{a}-$ tmìyadrști), ${ }^{10}$ and is to be explained as an "aberration relative to the things which constitute the pseudoperson." ${ }^{11}$ According to the Yogācāra VinSg, which Vasubandhu most likely relied upon, ${ }^{12}$ satkāyadrști it to

${ }^{6}$ On prthagjanas in epistemological literature, see PVP D195a2-3/P227b6, PVT $\tilde{N} e$ D205b2/P253b2-3 (ad PV 3.217b; for the context, see Eltschinger 2005b: 168171); PVP D58a6/P66b1-2 (ad PV 2.140-141a; for the context, see Eltschinger 2005a: 415-416).

7 See Vetter 1990: 22-26 and Schmithausen 1987: II.517-519 (= n. 1421). On satkāyadrști in general, see Rahder 1932, Kośa 5.15-17 + nn. 2-3 (AKBh 281,17282,3 on AK 5.7), Tṛh 23,12 and 29,21, Traité II.737n. 3. On the reasons for such an identification (rejected by Vasubandhu, see AK 3.29c), see Eltschinger (2007a, Appendix D, §1).

8 According to PV 2.211 and PV 2.196. For a more complete list of conceptual equivalents, see Vetter 1990: 22-23.

9 PVT Je D252a6/P299b8-300a1 = PVSVṬ 401,23: satkāyadarśanād ātmātmīyābhiniveśāt $\mid$.

$10 \mathrm{AKBh}$ 281,20: ātmadṛștir ātmīyadṛștir vā satkāyadrșțih |, and AKBh 281,24: ātmātmīyadrșțir eva satkāyadrșțịh|.

${ }^{11}$ See AKBh 290,19-21: api cānayor dṛstyoh svadravyasammūḍatvād aparapīdāpravrttatvāe ca | svargatṛṣnāsmimānayor apy evam prasangah $\mid$ sahajā satkāyadṛștir avyākrtā | yā mrgapakșinām api vartate | vikalpitā tv akuśaleti pūrvācāryāh |. English translation of Kośa 5.41 in Pruden 1991: III.798. See also AKVy 463,8-10: svadravyasammūạhatvād iti. svasantatipatitānām upādānaskandhānām ātmātmìyatvena grahaṇāt svadravyasammūụhā satkāyadṛștih|.

12 See Kritzer 2005: 292-293 ("Samghabhadra identifies this as the opinion of the sūtra-master [T. 1562: 618a17-19] and refutes it"). The first of the two passages quoted by Kritzer (2005: 293) runs as follows (VinSg P112b6-113a1): de la 'jig tshogs la lta ba gà́ źe na | ñe bar len pa'i phun po lina po dag la bdag gam bdag gir 
be defined as "the false view of self and one's own (ätmātmīyadrști), clinging (abhiniveśa) and 'mentalization' (sems la 'jog pa) with regard to the five constituents-of-personality being clung to (upādānaskandha)." According to all the schools mentioned - the Yogāaaras, the Sautrāntikas, and epistemologists such as Dharmakīrti - this false view of self is twofold, viz. speculative (parikalpita VinSg, ASBh, LAV, PVP, PVT, vikalpita AKBh) and innate/spontaneous (sahaja). ${ }^{13}$ The speculative false view of self characterizes heretics (anyatīrthya, VinSg), i.e., substantialist philosophers such as Sānkhyas and Vaiśeșikas (AKVy), ${ }^{14}$ and arises out of the meditation on (heterodox) treatises (śāstracint [an] ādi, PVT $).{ }^{15}$ The innate view of self is common to puerile worldly people (bālaprthagjana, $\mathrm{VinSg}$ ) as well as to animals like antelopes and birds (mrgapakșin, VinSg, AKBh) ${ }^{16}$ and arises out of beginningless latent tendencies (anādivāsanā, PVṬ). ${ }^{17}$ According to Dharmakīrti, both the speculative and the innate false views of self characterize the type of living beings traditional Buddhist scholasticism classifies as ordinary persons.

1.3. Pratītyasamutpāda. Nescience traditionally forms the first link in the Buddhist twelve-membered chain of dependent origination (pratityasamutpāda) and as such at least indirectly conditions thirst or craving (trṣna $\bar{a}$, or love, sneha, or desire, rāga). This craving is in turn regarded as the cause of suffering (duhkhahetu), i.e., the factor that prompts deluded people to act in order to quench their thirst, hence to

ba lta ba dan $\mid$ mñon par źen pa dañ sems la 'jog pa gan yin pa de ni ‘jig tshogs la lta ba źes bya'o $\|$ de'añ rnam pa gñis su rig par bya ste | lhan cig skyes pa dan kun brtags pa'o $\|$ de la lhan cig skyes pa ni byis pa so so'i skye bo thams cad dan tha na ri dags dan bya rnams kyi yan் yin no $\|$ kun brtags pa ni gźan mu stegs can rnams kyi yin par blta bar bya'o $\|$.

${ }^{13}$ LAV 117,17-118,13, AKBh 290,19-21 (see n. 11 above), VinSg (see n. 12 above), PV 2.199 (see n. 47 below). Note that Prajñākaragupta and Manorathanandin call the first of these two kinds of satkāyadrșți "ābhisamskārikā," Manorathanandin defines it as skandhavyatiriktātmādhyavasāyinī (see PVA 139,27-28 and PVV 79,2023).

14 AKVy 463,17-18: yā ātmavādibhih kapilolūkādibhir vikalpitā |.

15 PVT $\tilde{N} e$ D131b6-7/P162a7-8: kun tu brtags pa ni bstan bcos sems pa la sogs pa' $i$ sgo nas byun ba'o $\|$ lhan cig skyes pa ni thog ma med pa'i bag chags las byun ba'o $\|$.

${ }^{16}$ See nn. 11 and 12 above.

17 See n. 15 above. 
be bound to samsāric existence. ${ }^{18}$ Dharmakīrti devotes many pratītyasamutpāda-like passages to account for the rise of craving and the other defilements out of the belief in the person. One of the clearest runs as follows ${ }^{19}$ : "The one who sees a self has a constant love for this [self, thinking of it as] 'I'. Because of [this] love [for the self] he craves for the delights [for that self, and this] thirst conceals [from him] the drawbacks [of the things he deems conducive to these delights]. Seeing [but] qualities [to these things], he craves [for them thinking of them as having to become] 'mine', and appropriates $(u p \bar{a} \sqrt{d} \bar{a})$ the means [that are conducive] to them. Therefore he [remains] in samsāra as long as he clings to [that] self." These texts exhibit the traditional chain that links nescience, craving, appropriation (upādāna) and (re-)existence (bhava[/jāti]), but fail to inform us further about the rise of passions or defilements other than craving. The PVSV provides us with the most exhaustive picture of Dharmakīrti's account of the genealogy of defilements ${ }^{20}$ : "The birth of all kinds of [moral] faults is due to the [false] view of self [i.e., to the clinging to self and one's own, and] this [false

${ }^{18}$ See PV 2.146a (duḥkham samsārinah skandhāh) and PV 2.185d (tasmāt tṛ̣ṇā bhavāśrayah) in Vetter 1990: 53 and 88.

19 PV 2.217-218: yah paśyaty ātmānam tatrāsyāham iti śāsvatah snehah | snehāt sukheṣu tṛsyati tṛṣnā doṣāms tiraskurute \| guṇadarśī paritṛ̣yan mameti tatsādhanāny upādatte | tenātmābhiniveśo yāvat tāvat sa samsāre $\|$.

20 "Genealogy" as a free rendering of Karnakagomin's krama (lit. sequence, succession; PVSVṬ 401,25-26: kena punah kramena doṣānām satkāyadarśanād utpattih |). Satkāyadarśana is the prabhava (PVSV 111,11, gl. utpattikārana PVSVT 401,20), the mūla (PV 2.196), the ekayoni (PV 2.211) of the defilements. PVSV 111,13-20 (together with PV 1.222): sarvāsām doșajātīnām jātih satkāyadarśanāt $\mid$ sāvidyā tatra tatsnehas tasmād dveșādisambhavaḥ \| na hi nāhạ̣ na mameti paśyatah parigraham antareṇa kvacit snehah | na cānanurāginah kvacid dveșah | ātmātmīyānuparodhiny uparodhapratighātini ca tadabhāvāt $\mid$ tasmāt samānajātīyābhyāsajam ātmadarśanam ātmīyagrahạ̣ prasūte| tau ca tatsneham sa ca dveșādīn iti satkāyadarśanajāh sarvadoṣāh | tad eva cājñānam ity ucyate|. See also PV 2.196ac: mohaś ca mūlam doṣānām sa ca sattvagraho vinā | tenāghahetau na dveșah ... "Delusion is the root[-cause] of [moral] faults, and this [delusion] consists in the belief in a [personal] being. In the absence (vina $)$ of this [belief, there can be] no aversion for a cause of evil (agha) [since the error of an injury to the self does not occur for one who does not see any self]." PV 2.211: ātmagrahaikayonitvāt ... rāgapratighayoh ... "Because both desire and hostility have the belief in a self as their only source." PV 2.212cd: tanmūlāś ca malāh sarve sa ca satkāyadarśanam \|. "All the defilements have this [delusion] as [their] root[-cause], and this [delusion] is the [false] view of the self." On this point, see Franco 2001: 295-296. 
view of self] is nescience [itself]; with regard to the [object which is clung to as being self and one's own arises] love for those [i.e., for self and one's own, and] from this [love] are born such [evil defilements] as aversion. Indeed, the one who, without grasping (parigraha), sees that there is neither I nor mine, does not love anything and, [being so] unattached, does not hate anything [either], for there is no [aversion] for that which does not hinder the self or one's own, nor of that which opposes the [said] hindrance. ${ }^{21}$ Therefore the [false] view of self, which is born from the repeated habit (abhyāsa) of the [previous very] same [false view of self], generates the [false] view of one's own. Both of them then [produce] love for those [two things, self and one's own], and this [love in turn generates] such [evil passions] as aversion. Therefore all [moral] faults are born from the [false] view of self, and it is this [false view of self] that is called 'ignorance' (ajñāna) [in our doctrinal system]." Provided, once again, that he has not yet gotten rid of those defilements that an ordinary person can eliminate by means of the mundane path of cultivation, the prthagjana is first and foremost typified by his erroneous superimposition of ego-related aspects onto the selfless constituents of reality, and by the correlative defilements that make him slave to samsāra and suffering.

\section{The Idea of a Way Out}

2.1. Gotra, kalyānamitra and the śrutamaȳ prajñ̄ā. There are some reasons to believe that at least some of Dharmakirti's commentators and epigones assented to the (mainly) Mahāyānist doctrinal complex that entails such key notions as gotra ("family"), kalyānamitra ("spiritual friend"), bodhicitta ("thought of enlightenment") and pranidhāna ("vow"). ${ }^{22}$ Asked to account for the cause(s) of a Bodhisattva's first im-

${ }^{21}$ See PV 2.219: ātmani sati parasamjñāa svaparavibhāgāt parigrahadveșau | anayoh sampratibaddhāh sarve doșạh prajāyante \| "When there is [a notion of] a self, [there is] a notion of the other; from [this very] distinction between a self and another, both grasping (parigraha) and aversion [are generated and], bound to these two, all the [moral] faults arise."

22 On gotra, see PVP D16a5/P18a3-4, PVT N Ne D88b5/P108a3-4, TSP K872,17/Ś1055,14-20 and PVV 20,12-17 (on this passage, see Franco 1997: 24); on bodhicitta and pranidhāna, see PVP D85a5/P98a1 (byan் chub kyi sems sn்on du son ba can gyi brtse ba) and PVV 79,9 (pranidhāna). See Eltschinger (2008, §§3.2-3 and 5.4). 
pulse toward the practice of compassion (karunāa), Devendrabuddhi, Sākyabuddhi and Kamalaśîla mention a particular type of living being (sattvaviśeșa, PVP), i.e., a (specific) family (gotra PVT, gotraviśeșa TSP) that we must understand as consisting of the bodhisattvagotra ("family of Bodhisattvas," in contrast to the families of the Hearers [śrāvakagotra] or Buddhas-for-themselves [pratyekabuddhagotra]). Indeed, the bodhisattvagotra is intrinsically linked to compassion. ${ }^{23} \mathrm{His}$ belonging to this family causes the Bodhisattva, still as an ordinary person, to generate the (conventional) thought of enlightenment and to make the vow of striving for awakening in order to alleviate the suffering of living beings. ${ }^{24}$ Elsewhere I have argued that Dharmakīrti's PV 2.131cd-132ab can be interpreted as providing us with a functional equivalent to the arising of the thought of enlightenment ${ }^{25}$ : "[Wishing to calm other people's suffering,] the compassionate [Bodhisattva] engages in [the cultivation of] means to [calm suffering] in order to eradicate [his own] suffering: for whom the goal (upeya) and [its] cause remain imperceptible (paroksa), it is indeed a difficult task to [correctly] teach [others about them]." True to a well-documented Yogācāra tradition, Devendrabuddhi, Śākyabuddhi and Ravigupta also consider companionship with and service ( $\operatorname{sev} \bar{a})$ to a "spiritual friend" to be instrumental (< pratyaya) in the the rising of the first impulse of a (novice) Bodhisattva toward the practice of compassion. ${ }^{26}$ In addition to his exhortation to engage in compassion, this kalyannamitra's main function is to teach Dharma or the path toward awakening (bodhimārga). From such a Buddha or skilled Bodhisattva, the yogin hears or learns $(\sqrt{s} r u)$ the Good Law (saddharma) or Word (pravacana) of the Buddha ${ }^{27}$ : this is the so-called wisdom born of listening (śrutamaȳ prajñ $\bar{a}$ ), which, just

${ }^{23}$ See MSA 3.5 together with MSABh 11,18, Maithrimurthi 1999: 268 and nn. 153154.

${ }^{24}$ See BoBh D10,12-13/W15,11-12 and MSABh 15,2.

${ }^{25}$ PV 2.131cd-132ab: dayāvān duhkhahānārtham upāyeșv abhiyujyate \| parokṣopeyataddhetos tadākhyānam hi dușkaram |. See Eltschinger (2008, §§5.3-5).

${ }^{26}$ See Eltschinger $(2008, \S 3.4)$.

27 See Eltschinger (2008, n. 75). Interestingly, the Buddha's Word seems to be ninemembered (navāinga) rather than twelve-membered (dvādaśāinga) in the few places it is mentioned by the epistemologists. See PVP D120b4-5/P139b3 (together with PVT $\tilde{N} e$ D150b3-4/P186a2-3) and TSP K877,4-6/Ś1062,7-9. On this distinction, see Lamotte 1976: 157-159. 
like the following "wisdom born of (rational) reflection," the (novice) Bodhisattva obtains still as an ordinary person. ${ }^{28}$

2.2. Cintāmaȳ prajñ $\bar{a}^{29}$ The wisdom born of (rational) reflection mirrors the concerns of a human "type" who is ideally possessed of two properties: first, his desire to engage (pravrttikama) in a religious path and second, his practical rationality (prekșāvattva, prekșāpūrvakāritva). At this stage, the (novice) Bodhisattva submits the scriptural contents he has previously heard/learnt to a rational inquiry (yukti) or examination (parīkșa, vicāra, etc.) that mainly proceeds by means of inference (anumāna, sādhana). Wisdom born of (rational) reflection consists in an ascertainment (niścaya, nirnaya) of scriptural contents through the so-called means of valid cognition (pramāna), and results in (a) cognition(s) that is/are termed "agreeing with the means of valid cognition" (pramānasamvādin), i.e., whose objects (artha) have proved to stand critical analysis by means of pramānas (pramāna[pari]śuddhārtha, pramāna[pari]drștārtha) and hence are deemed to be worthy of (religious) exertion/endeavour (abhiyogārha). Typical of this kind of object are the four Noble Truths, which form the core or principal point (pradhānārtha) of the Buddhist teaching and which a rational person subjects to inferential investigation in order to assess the reliability (avisamvāditva) of scriptures (ägama). In a philosophical narrative, ${ }^{30}$

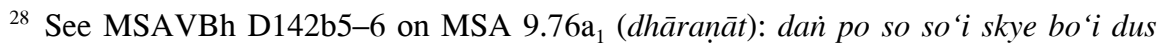

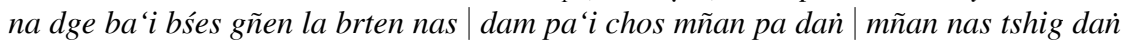
don gzun ba dan gzun ba rnams bsam źin ... "First when [still] an ordinary person (prthagjanakāle), [the Bodhisattva] learns ( $\sqrt{s} r u)$ the Good Law (saddharma) relying on a spiritual friend (kalyānamitram āśritya), grasps $(\sqrt{g r a h})$ the word (vyañjana?) and the meaning (artha) after he has learnt (śrutvā) [them] and reflects $(\sqrt{\text { cint })}$ upon the [things thus] grasped $($ grhit $t$ ) ..."

${ }^{29}$ On the cintāmaȳ prajñ $\bar{a}$, see Eltschinger (forthcoming 1). The present section is but a summary of (parts of) the second part of this study.

${ }^{30}$ PV 2.132cd-135: yuktyāgamābhyām vimṛsan duḥkhahetum parīkṣate \| tasyānityādirūpam ca duhkhasyaiva viśeșaṇaih | yatas tathä sthite hetau niṿ̂ttir neti paśyati $\|$ phalasya hetor hānārtham tadvipakșam parīsșate | sādhyate tadvipakṣo 'pi heto rūpāvabodhatah || ātmātmīyagrahakrtạ snehah samskāagocarah | hetur virodhi nairātmyadarśanam tasya bādhakam \|. "Reflecting on [the means and the goal] through reasoning (yukti) and the Scriptures (ägama), [the compassionate Bodhisattva] inquires into the cause of the suffering [that is to be eradicated] and, through the particularities of suffering itself, [he inquires also] into the impermanent nature, etc., of the [cause in question]. Since in this way [he who wishes to eradicate suffer- 
Dharmakīrti relates how the compassionate Buddha-to-be, rationally and scripturally (yuktyāgamābhyām), reflects upon the cause of suffering and the antidote (vipaksa, pratipakșa) to that cause. The Bodhisattva first determines love (sneha, i.e., craving), itself generated by the belief in self and one's own (ätmātmìyagrahakrta), to be the (destructible) cause of suffering. He then identifies the means (upāya) or factor (dharma) that is able to oppose, contradict (vi $\sqrt{r} u d h, \sqrt{b} \bar{a} d h)$ and destroy the cause of suffering: this antidote or antagonistic factor consists in the view or perception of unsubstantiality or emptiness (nairātmyadarśana or ${ }^{\circ} d r s \underline{t} i$, śünyatādrști). In the stage of rational reflection, pramānas (i.e., inference) ascertain or determine the real aspects (bh $\bar{u}$ tāka $r a$, impermanence, painfulness, emptiness in the sense of the lack of one's own [AKBh 400,2-3], selflessness, etc.) of entities and hence provide the reflecting yogin's cognition with aspects ( $\bar{a} \bar{a} r a)$ and objects (älambana) that contradict, oppose or counteract the superimpositions (samāropa, etc., namely, permanence, delight, one's own, self, etc.) that ignorance, as a generalized erroneous perception (mithyopalabdhi), is responsible for. What the yogin is intent upon here is nothing other than following a path that will enable him to counteract (pratipakșamārga) the adventitious (ägantuka) filth of passions and

ing] sees that there is no end to the effect so long as the cause remains, he inquires into the antidote of the [cause of suffering] in order to eliminate it. [As for the dharma forming] the antidote of that [cause, it] is also ascertained by the [Bodhisattva's] knowledge of the nature of the cause [itself]. [That] cause [is] attachment bearing on dispositions, [an attachment which] is due to the belief in self and one's own; [as for] the antidote to that [cause, it is] the perception of selfnessness which opposes it." On this important passage, see inter alia Franco 1989: 84-90, Vetter 1990: 11-12, Eltschinger 2005: 397-408, Eltschinger (forthcoming 1, §2.4) and Dunne 2006: 505-507. It is easy to show that this passage narrates the Bodhisattva's rational determination of the Noble Truths. PV 2.131cd-132ab present us with a mahāyānist account of the Bodhisattva's being struck by his own as well as the other living beings' suffering (duhkhasatya). This of course needs not be further investigated since duhkha is but an empirical fact. PV 2.132c-133ab and $135 \mathrm{ac}_{1}$ account for the Bodhisattva's inquiry into the origin of suffering (samudayasatya), whereas PV $2.134 \mathrm{bd}$ and $135 \mathrm{c}_{2} \mathrm{~d}$ describe his determination of the path leading to the destruction of suffering (märgasatya). As to the destruction of suffering (nirodhasatya) itself, it cannot be made the object of an analysis, but merely be hinted at, which we can observe in PV 2.133cd-134a, with its characteristic allusion to nivrtti. On that passage, see in general Eltschinger 2005a: 397-408 and Eltschinger (forthcoming 1, §2.4). 
hence establish his mind $($ citta $=$ vijñāna $)$ in its naturally radiant (prabhāsvara) and flawless (nirāsrava) condition.

\section{The Path to Salvation}

3.1. Pratipakșamārga. ${ }^{31}$ According to Dharmakīrti, nescience consists in an erroneous perception (PV 2.213) that he identifies with the innate false view of self. This false view gives rise to thirst or craving, which is regarded as the cause of suffering. The yogin who is eager to rid himself of suffering will thus have to eliminate craving and other defilements by eradicating their cause. In other words, he will have to develop and cultivate the perception of unsubstantiality or emptiness, which acts as an antidote or antagonistic factor to the false view of self, in order to free himself from craving and suffering. This antagonism between avidy $\bar{a}=$ satkāyadrști and nairātmyadarśana is based on the fact that these mutually opposing factors display contrary aspects of the object (viparìtālambanākāra). ${ }^{32}$ Two stanzas of PV 2 account well for this mutual incompatibility and for Dharmakīrti's general conception of the yogic path" ${ }^{33}$ : "Having[, due to nescience,] superimposed sixteen unreal aspects, viz. 'lasting', 'pleasant', 'mine', 'I' ${ }^{34}$ etc., on the four [Noble] Truths, one experiences craving [for such a superimposed object as delight, etc.]. ${ }^{35}$ The correct view, well cultivated, ${ }^{36}$ destroys the thirst together with its suite [of defilements such as selfishness, envy, etc., ${ }^{37}$ insofar as this correct view], with regard to these [four Noble

31 Pratipakșamārga in PVṬ Je D252a1-2/P299a8-b1 = PVSVṬ 401,12-13.

32 PVP D115b3/P134a4: 'gal ba de yan்* dmigs pa'i rnam pa phyin ci log pa'i sgo nas yin no $\| .{ }^{*}=$ ma rig pa dan bdag med pa ñid mthon ba 'gal ba according to PVT $\tilde{N} e$ D147a3/P181b5-6.

${ }^{33}$ PV 2.270-271: sthiram sukham mamāham cetyādi satyacatuṣtaye | abhūtān șodaśākārān āropya pariț̣syati || tatraiva tadviruddhārthatattvākārānurodhinī| hanti sānucarām tṛ̣nạ̣̣̄ samyagdṛ̦țị̣ subhāvitā \|. On anurodhin, see Vetter 1990: 27n. 14.

${ }^{34}$ See PVP D115b4-6/P134a5-8 and PVT Ñ $e$ D147b1-3/P182a5-8.

35 According to PVP D116a2-3/P134b4-5, Dharmakirti shows now that the path is the counteracting factor because it is possessed with aspects that are contrary to the ones superimposed by nescience.

36 According to PVP D116a6/P135a1, once the perception of unsubstantiality has become coessential (sātmībhüta) with the mind through cultivation; on PVV 103,8 (subhāvitā sādaranirantarad̄̄rghakālābhyāsaprāptavaiśadyā), see below §3.5.

${ }^{37}$ Mãtsarya and īrṣyā according to PVP D116a6/P135a1-2 and PVV 103,8-9 . 
Truths], conforms to (anurodhin) the real aspects of the thing ${ }^{38}$ which are contradictory to the [ones falsely ascribed by ignorance]." 39 Nescience has one superimpose or grasp such unreal aspects as permanence. ${ }^{40}$ Once craving and all kinds of defilements arise, they bear upon objects whose aspects have been superimposed. ${ }^{41}$ Now the perception of unsubstantiality entails or goes along with the sixteen real aspects of the Noble Truths ${ }^{42}$ i.e., is provided with aspects that are contradictory to those superimposed by nescience. Cultivating this perception to its maximum degree of intensity, i.e., up to the point where it becomes essential to the mind or the psychic stream, will annul not only the innate false view of self, but also all the defilements that it gives rise to by providing them with (pseudo-)objects. Such is the basic structure and goal of Dharmakīrti's path (mārga). Though this structure remains basically the same for all types of Buddhist yogins (Śrāvakas, Pratyekabuddhas and Bodhisattvas), differences are mainly concerned with the initial motivation (nimitta, prayojana) guiding the yogin, and hence with

${ }^{38}$ Literally: "aspects which constitute the true reality of the thing." See Devendrabuddhi's and Manorathanandin's explanations in PVP D116a3/P134b5 and PVV 103,68 respectively.

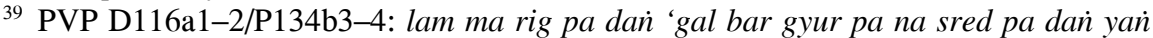
don gyis 'gal ba yin no źes bstan to \|. "[Dharmakīti] teaches [here] that if the path is contradictory to nescience, it is [then] indirectly (arthät) contradictory to craving too."

${ }^{40}$ PVP D115b6-7/P134a8-b2 presents us with the following unreal aspects with regard to trṣnālakșano duhkhahetuh: erroneous superimposition of asamudaya ${ }^{\circ}$, ahe$t^{\circ}$, apratyaya ${ }^{\circ}$ and aprabhavākāra. PVT $\tilde{N} e$ D147b3-5/P182a8-b2 supplies for Dharmakīti's and Devendrabuddhi's ${ }^{\circ} \bar{a} d i$ s in the following way: superimposition of anirodha ${ }^{\circ}$, aśānta ${ }^{\circ}$, apranitta ${ }^{\circ}$ and anihsaranākāra with regard to nirodhasatya; superimposition of $a m \bar{a} r g a^{\circ}$, anyāy $a^{\circ}$, apratipatti ${ }^{\circ}$ and anairyānikākāra with regard to mārgasatya.

${ }^{41}$ Note PVT $\tilde{N} e$ D147b5-7/P182b2-4: sgro btags nas ni yons su sred ces bya ba'i tshig gis log par sgro 'dogs pa sñon du son ba can gyi sred pa ñid gsal bar bstan pa yin no || sgro 'dogs pa'i yul la 'jug pa'i sred pa de yan் sgro 'dogs pa'i rnam pa ñid yin la | sgro 'dogs pa'i rnam pa can gyi yul can gyi ñon mońs pa dañ ñe ba'i ñon mońs pa thams cad ñid ma rig pa ñid yin pa de ltar na de 'i ran bźin can ñid kyan் bstan pa ñid yin no $\|$.

42 See AKBh 343,16-19 together with Kośa 6.163 (Pruden 1991: III.930) and, for definitions, AKBh 400,1-401,17 together with Kośa 7.30-39 (Pruden 1991: IV.1110-1116). 
the length of the cultivation as well as with the quality or scope of the salvational result. ${ }^{43}$

3.2. Darśanamārga. When he practiced rational reflection on scriptural contents, the yogin was still an ordinary person, and the compassion he was endowed with still bore upon a hypostasised notion of living beings (sattvālambana) ${ }^{44}$ To put it in a more traditional way, we could say that at this stage, the yogin was a Bodhisattva who has formed the initial resolution (prathamacittotpādika), abiding in the so-called adhimukticaryābhümi ("stage of zealous conduct"). The supramundane noble factors that an ordinary person is per definitionem bereft of are those that arise on the so-called path of vision/seeing (darśanamārga), which (normally) opens up the Buddhist religious path properly speaking and coincides, in a Mahāyānist perspective, with the Bodhisattva's entrance into the first stage (most commonly known as the "joyful stage," pramudita bhümih). ${ }^{45}$ The state of an ordinary person ceases as soon as the yogin has entered the path of vision ${ }^{46}$ : at this time, the yogin becomes a noble person (ärya[pudgala]) and enters the path of those who are undergoing religious training (śaikșamārga). Like all the path structures that have been inherited from the Vaibhāsika abhisamayavāda, Dharmakīrti's path is basically twofold, divided into a path of vision and a path of cultivation (bhāvanāmārga, though both are here included in the broader category of bhāvanā). Dharmakīrti spells it out as follows ${ }^{47}$ : "[Objection:] Inexistence (abhava) [i.e., liberation from samsāra,]

${ }^{43}$ For differences between the darśanamārgas of the Śrāvakas and the Bodhisattvas, see MS 3.15.

44 PVṬ Je D24b6/P29b2-3 = PVSVṬ 53,9: sattvālambanā prthagjanānām |. "sattvālambanā" refers itself to karuna and more generally, to the four "immeasurables" (apramāna).

45 See e.g. BoBh D223,22-25/W326,22-327,1.

46 There are at least two interpretations with regard to the nature of the noble factors referred to in the Vaibhāsika definition of the state of an ordinary being: "To the non-acquisition of which factors does the nature of an ordinary person refer? [According to two interpretations, it is maintained that the nature of an ordinary person] is either the general non-acquisition of all (sarva) noble factors or the [specific] non-acquisition only of the presentiment of the knowledge of the doctrine with regard to suffering (duhkhe dharmajñānakșānti)." Nyāyānusāra 399b as translated in Cox 1995: 203. See also Kośa 6.182-183n. 1 (Pruden 1991: III.1056-1057n. 165).

${ }^{47}$ PV 2.199ac: satkāyadṛster vigamād ādya evābhavo bhavet | mārge cet sahajāhāner na... 
should occur [already] on the initial path [i.e., during the path of vision] ${ }^{48}$ for the [false] view of self[, which is the cause of the connection to a new birth,] ceases [at that time]. ${ }^{49}$ [Answer:] No, because [at that time] one does not rid oneself of the innate [false view of self]." We see thus that Dharmakirti also accepted the two above-mentioned satkayadrsstis: whereas the speculative one is to be eliminated by the path of vision, the innate one, which arises from beginningless latent tendencies, can only be eliminated by the path of cultivation (bhāvan $\bar{a}$ märgaheya, PVT, PVV). Since one does not rid oneself of the innate satkāyadrsțti, i.e., the cause of rebirth (punarbhavahetu, PVP), by the path of vision, ${ }^{50}$ love for the self (àtmasneha PVP, trṣnā PVV) continues beyond the path of vision and results in re-existence (punarbhava PVP, janmaprabandha PVV). ${ }^{51}$ This amounts to saying that such Bud-

48 PVP D85a7/P98a4: lam dan po ste | mthon ba'i lam; PVV 79,19: ādya eva mārge darśanamārge. According to Śākyabuddhi (PVṬ Ñe D131b5/P162a6), Dharmakīrti calls the darśanamārga the "initial path" because darśanamārga occurs before the path of cultivation, the path of those who are undergoing religious training (saiksa$m \bar{a} r g a$ ) and the path of those who no longer need religious training (aśaikșamārga). On śaikșas and aśaikșa = arhat, see AKBh 365,16-366,7 and Kośa 6.230-233. The category of Śaikșa covers seven types of saints or noble persons (äryapudgala) according to AKBh 365,18-19 (sapta pūrvoktāh pudgalāh śaikșā iti |), viz., four "candidates" (pratipannakāh) and three "abiders" (phale sthitāh, AKBh 366,1-2): the ones who are in the progress of realizing the four states of Srotaāpanna, Sakrdāgāmin, Anāgāmin and Arhat, and those who in fact are Srotaāpanna, Sakṛāgāmin and Anāgāmin (AKBh 366,2-3). On the Srotaāpanna, see AK 6.29cd together with AKBh 353,20-22 (Kośa 6.194, Pruden 1991: III.953); on the Sakrdāgāmin (devān gatvā sakṛn manușyalokāgamanāt sakrdāgāmī, AKBh 358,1-2), see AK 6.35 together with AKBh 358,1-3 (Kośa 6.208-209, Pruden 1991: III.964-965); on the Anāgāmin (kāmadhātvanāgamanāt, AKBh 358,16-17), see AK 6.36d together with AKBh 358,16-17 (Kośa 6.209-210, Pruden 1991: III.965-966).

49 Conclusion, PVP D85a7/P98a4-5: de yan mi 'gyur ba de 'i phyir bdag tu chags pa skye ba' $i$ mtshams sbyor ba'i rgyu ma yin no źe na |. "But it does not occur [at that time]; therefore, love for the self (ätmasneha) is not the cause of the connection to a [new] birth."

50 Note also PVP D121a1/P139b7-8 (about abāhyaśaikșas, i.e., Buddhist śaikṣas): lhan cig skyes pa' $i$ 'jig tshogs su lta ba ma spans pa 'i phyir ro $\|$.

${ }^{51}$ See PVP D85b1-2/P98a5-7: bdag tu lta ba'i rnam pa gñis te | kun brtags pa dan lhan cig skyes pa'o $\|$ kun tu brtags pa de ni de dag gis śin tu kun tu spyod pa'i chos ma yin pas na spans pas de ni skye ba'i kun nas 'chin ba'i rgyur mi 'gyur ro || 'jig tshogs su lta ba lhan cig skyes pa yan் srid pa'i rgyu gan yin pa de ni de dag ñid kyis spañs pa ma yin no $\|$ de ma spañs pa'i rgyu'i phyir bdag tu chags pa ma log pa ñid yin pa de ltar na yaì srid pa yod pa yin no \|. PVV 79,20-23: dvidhā hi satkāyadrștir 
dhist saints as the stream-enterer (srotaāpanna), the once-returner (sakrdāgämin) and the non-returner (anāgāmin) are still possessed of an innate erroneous nescience (*sahajāvidyā viparītā?) that they will have to eradicate by the path of cultivation. ${ }^{52}$

3.3. Bhāvanāmärga. At the end of the path of vision, the saiksas of the śâvaka type obtain the religious fruit or result (phala) they were a candidate for (pratipannaka) before entering the path. Depending on the extent to which they have, still as ordinary persons, eliminated the $b h \bar{a}$ vanāheya defilements by means of a mundane path of cultivation, ${ }^{53}$ they obtain the results of stream-enterer, once-returner and non-returner. ${ }^{54}$ As such they are reborn, respectively, seven times in the realm of desire ( $k \bar{a} m a d h \bar{a} t u$ ), or only once, or no more, before they reach emancipation from samsāra, i.e., nirvāna. The supramundane path of cultivation they

$\bar{a}$ bhis[a] $\operatorname{lnskārik\overline {~}}$ yā skandhavyatiriktātmādhyavasāyin̄̄ sahajā ca | tatra prathamā darśanamārge hīyate | na dvitīyā bhāvanāmārgaheyā $\mid$ sā ca mohas tṛ̣ṇāyāś ca hetur iti bhavati janmaprabandhah |. PVT $\tilde{N}$ e D131b7/P162a8-b1: de dag ñid kyis spañs pa ma yin no zes bya ba ni thog ma med pa'i bag chags las byun ba de ni bsgom pa' $i$ lam ñid kyis span bar bya ba ñid yin pa'i phyir ro $\|$. For a similar distinction between speculative-darśanaheya and innate-bhāvanāheya āvaraṇas, see Siddhi II.572 and Siddhi II.639-640.

52 PVT $\tilde{N}$ e D131b7/P162b1-2: bdag tu chags pa khas len pa ñid kyi phyir| rgyun du źugs pa la lhan cig skyes pa'i mi śes pa phyin ci log yod pa yin no źes bstan pa' $i$ phyir |. See also ASBh 62,3-4, as quoted by Schmithausen (1987: II.440n. 931): sahajā satkāyadrṣțir bhāvanāprahātavyā: yām adhișthāya utpannadarśanamārgasyāpy āryaśrāvakasyāsmimānah samudācarati |. "Innate [false] view of self is to be eliminated through cultivation: based on this (yām adhisțhāya) [innate false view of self], egotism (asmimāna) occurs even in a Noble Hearer (äryaśrāvaka) in whom the path of vision has arisen." ASBh 62,9-11, as (partly) quoted by Schmithausen (1987: II.440-441n. 932): darśanamārgeṇa prahịnaparikalpitasatkāyadṛștimalasyāpy āryaśrāvakasya pūrvābhiniveśābhyāsakrtam ... ātmadarśanam anuvartate yat tat punar mārgabhāvanayā prahātavyam bhavati |. "Even in a Noble Hearer in whom the impurity consisting in the speculative [false] view of self has been eliminated by the path of vision, the [false] view of self, caused by the repeated habit of former clinging, goes on existing, which is still to be eliminated by the cultivation of the path."

${ }^{53}$ Laukikabhāvanāmārga at PVV 107,5-6; see also TS 3496-3497, and Kośa 6.iv-xi (Pruden 1991: III.xiv-xxii).

54 PVP D85a7/P98a4: rgyun du źugs pa la sogs pa; PVV 79,19: srotaāpannasya. PVT $\tilde{N}$ e D131b5-6/P162a6-7: rgyun du źugs pa la sogs pa źes bya ba la sogs pa'i sgras

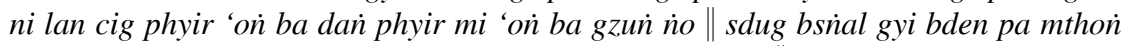
ba ñid kyis de dag gis 'jig tshogs su lta ba spanis pa yin no $\|$. 
still need in order to get rid of the remaining defilements is then extremely short. Highly different is the situation of the saiksa who is destined for Buddhahood and not for Arhatship, and who, still as an ordinary person, had made the vow to reach enlightenment in order to alleviate living beings' suffering by teaching them the path to liberation. As far as I can see, this Buddha-to-be still must rid himself of three major elements as he exits the path of vision. (1) Like Hearers and Buddhasfor-themselves, he will have to uproot the innate false view of self together with its attendant defilements, but (2) unlike Hearers and Buddhas-for-themselves, he will have to eliminate these defilements together with their traces or after-effects $(v \bar{a} s a n \bar{a})$, which regularly manifest themselves in Arhats through corporeal, vocal or mental deficiencies (kāyavākcittavaigunya). (3) The Buddha-to-be still must uproot the so-called undefiled nescience or ignorance (aklisțāvidy $\bar{a}$, or ${ }^{\circ}$ ajñāna, or ${ }^{\circ}$ sammoha). To put it technically, the Bodhisattva must eradicate two kinds of obstacles ( $\overline{\text { varana }}$ ) in addition to the innate false view of self: the obstacle that consists in the defilements together with their after-effect (savāsanakleśāvarana), and the obstacle that conceals the knowable (jũeyāvarana). ${ }^{55}$ Needless to say, this threefold uprooting demands an incomparably longer path of cultivation than that taken by Hearers and Buddhas-for-themselves. ${ }^{56}$ Whoever the yogin may be, the cultivation or repeated practice (abhyāsa) consists in the yogin's practicing (prayoga) or generating (utpädana, utpatti) repeatedly, "again and again" (punah punah, paunahpunyena), ${ }^{57}$ the salvational means, viz., the perception of unsubstantiality, in order to finally reach a direct perceptual realization ${ }^{58}$ (sākșâtkaraṇa) of it.

3.4. Anābhogatā and svarasavāhitva. Dharmakīrti's conception of a Bodhisattva's cultivation is based on a Mahāyānist path structure that

\footnotetext{
55 On all this, see Eltschinger 2005a: 408-436, and below $\$ 3.5$.

${ }^{56}$ On the duration of the various religious careers (and especially the one of Bodhisattvas), see Traité IV.1842, and n. 5 (pp. 1842-1843), and Siddhi II.731-733.

${ }^{57}$ Abhyāsa is defined as punah punar nairantaryenotpādanam (PVSVT 398,9), as paunahpunyenānādikālam utpattih (PVṬ Je D252b7-253a1/P300b6 = PVSVṬ 402,19), or else as punah punah prayogah (AKVy 649,26), or as punah punaś cetasi viniveśanam (NBT S11,18-19/M67,5).

${ }^{58}$ See PVP D54b7/P62a8, PVA 108,20 and 26, PVV 57,4, TS 3339-3340ab, TSP K16,1-3/Ś20,12-13, K876,17-19/Ś1061,14-16, passim.
} 
entails various stages (bhümi) as well as the parallel development of

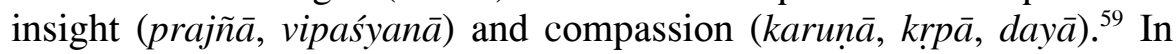
the most authoritative traditional accounts of a Bodhisattva's career $($ cary $\bar{a})$, the entrance into the eighth (or seventh) stage (acala $\mathrm{DBhS}$, niyata $\mathrm{BoBh}$, or the tenth abode, vihära $\mathrm{BoBh}$ ) stands out as a decisive turning point. The Bodhisattva is now possessed of the "presentiment that dharmas (ultimately) have no arising" (anutpattikadharmakșanti); from now on his progression is irreversible (avaivartika). Especially noteworthy is the fact that all the factors and operations characterizing him have now become spontaneous (< svarasena eva) on account of the intensity of the cultivation (bhāvanābāhulyāt) ${ }^{60}$ and develop without any intentional effort (anäbhogena). ${ }^{61}$ This pertains to the Bodhisattva's wisdom as well as to his compassion, which from now on can properly be termed "great compassion" (mahākaruña), and which no longer bears upon anything (anālambanā, because the Bodhisattva no longer sees sattvas or dharmas). ${ }^{62}$ Note should also be made that the entrance into the eighth (or seventh) stage coincides with the acquisition of "unfixed" nirvāna (apratișthitanirvāna). ${ }^{63}$

The epistemologists' assent to this complex of ideas can be easily documented. Dharmakīrti himself accepts the notion of an objectless compassion (anālambanā karuñā) ${ }^{64}$ which Śākyabuddhi and Karnakagomin declare to be proper to Buddhas and Bodhisattvas who, in contradistinction to ordinary persons and noble beings (ärya), have rid themselves of the clinging to the object-subject dichotomy. ${ }^{65}$ Moreover,

59 Note Devendrabuddhi's explanation of hetusampad in PVP D57b2/P65b2: bcom ldan 'das kyi thugs rje dan thabs goms pa rgyu yin no źes rgyu phun sum tshogs pa gsuñs pa yin no \|. Upāyābhyāsa = nairātmyadarśanābhyāsa = prajñābhyāsa. Devendrabuddhi's prayoga at PVP D57a1-3/P64b7-65a2 (see Eltschinger 2005a: 405n. 45) makes it perfectly clear that nairātmyadarśana is prajñā.

${ }^{60}$ See BoBh D219,17-220,2/W320,24-321,2 and Eltschinger (2008, §4.3 and n. 103).

${ }^{61}$ See DBhS (VII F) 58,6-9, (VIII C) 64,15-16 and 25-26, (VIII K) 67,10-19, and (VIII C) 64,26-27. This is also termed the anābhogacarya at LAV 43,9 (see Suzuki 1999: 221-230).

62 See Eltschinger $(2008, \S 4)$.

${ }^{63}$ On the apratisthitanirvāna, see the bibliographical references in Lamotte 1973: II.47*-48*; see also Siddhi II.671-672 and Nagao 2000: 2-4.

${ }^{64}$ See PVSV 9,14-15.

${ }^{65}$ PVṬ Je D24b6-7/P29b3-4 = PVSVṬ 53,9-10: anālambanā grāhyagrāhakābhiniveśavigatānām buddhabodhisattvānām |. 
Dharmakīrti associates "great compassion" (mahatī krpā) with Bodhisattvas who are possessed of a durable substratum (sthirāśraya) and remain in samsāara (in contradistinction to Śrāvakas and Pratyekabuddhas). ${ }^{66}$ Last but not least, Dharmakīrti argues at length that compassion proceeds spontaneously (svarasena) as it becomes the very nature (svabhāva) of the psychic stream and no longer requires any effort (yatna) in order to increase. ${ }^{67}$ The same doctrinal pattern also seems to obtain in the case of discernment (vipaśyana), which, defined as "wisdom bearing upon unsubstantiality" (nairātmyālambanā prajñā), ${ }^{68}$ is equivalent to the already mentioned perception of unsubstantiality and the counteracting path it defines. The yogin's nearly endless cultivation of nairātymadarśana gradually results in the latter's becoming "coessential" or "conatural" to the mind (citta), a process (or rather its result) the epistemologists usually describe in terms of sātmya or sātmíbhāva: after a certain point, the mind or the psychic stream (santāna) acquires discernment as its own nature, ${ }^{69}$ which amounts to saying that it is coessential with the perception or cultivation of unsubstantiality, also referred to as the path or the antidote of the defilements (dosapratipaksa/ ${ }^{\circ}$ vipaksa $) .{ }^{70}$ Devendrabuddhi uses the expression *anābho-

${ }^{66}$ See PV 2.197-198, below n. 73.

${ }^{67}$ See PV 2.120-131ab, and Eltschinger (2008, §2) for an English translation and explanations.

${ }^{68}$ PVT $\tilde{N} e$ D134b3/P166a1: lhag mthon yin la źes bya ba bdag med pa la dmigs pa' $i$ śes rab bo \|. Note also BhK 1.219,23-220,4, where vipaśyanā bears upon the unsubstantiality of all dharmas (sarvadharmanihsvabhāvatālambana), and Kamalasīila's definition of vipaśyanā at BhK 3.5,17-20: bhütapratyavekșanā ca vipaśyanocyate | bhūtam punah pudgaladharmanairātmyam | tatra pudgalanairātmyam yā skandhānām àtmātmìyarahitatā | dharmanairātmyam yā teșām eva māyopamatā |. "La vipaśyanā est une analyse correcte. Elle est correcte parce [qu'elle porte] sur l'inexistence de l'individu et sur l'inexistence des dharma. L'inexistence de la personne consiste en ce que les agrégats sont privés de Moi; l'inexistence des dharma est le fait qu'ils sont pareils à une magie.” Translation in Lamotte 1987b: 340.

${ }^{69}$ PVSVṬ 400,13: vipaśayanāsvabhāvasya; PVP D90a1/P103b8: rañ bźin yaì lhag mthon ba yin; PVSVṬ 401,14: vipaśyanāsātmani sthitasya (= PVṬ Je D252a2, as against P299b1).

70 PVSV 110,18 (sātmībhāuāt - see PVṬ Je D249a6/P295b1 = PVSVT 398,11, where the santāna is said to be sātmībhütadosapratipakșa, to be treated as a bahuvrīhi compound), PVSV 110,24 (dosavipaksasātmatve, where the dosavipakșa is nairātmyadarśana according to PVṬ Je D250b1/P297a5-6 = PVSVT 399,17), PVSV 111,3 (vipakșasātmanaḥ puruṣasya), PVSV 111,8 (pratipakșasātmya ${ }^{\circ}$ ); PVV 
ganairātmyadarśanaḥ purușah to refer to this state, ${ }^{71}$ while Sākyabuddhi regards nairātmyadarśana as proceeding spontaneously (svarasavāhitva, or *svarasapravartakatva). ${ }^{72}$ As for "unfixed" nirvāna, an allusion (at least according to Śākyabuddhi) is found in a passage in which Dharmakīrti contrasts Śrāvakas and Pratyekabuddhas on the one hand, and Bodhisattvas on the other ${ }^{73}$ : "It is not true $(n a)$ that there [can be] no liberation [from samsāra], because once the previous samskāra [= karman] has been exhausted, there is no connection to another [painful birth. However,] those whose samskära is of unexhausted force do remain [in samsāra out of compassion, after having meditated upon the benefit of the other living beings, ${ }^{74}$ and are] immaculate. And because compassion is weak [since it has not been cultivated intensively before], the effort in order to remain [in samsāra] is not great [and hence the abode in samsāra does not last]; on the contrary $(t u)$, [those] whose commiseration $(k r p \bar{a})$ is great do remain [in samsāara, being entirely] devoted to the other [living beings]." It is commonplace in Mahāyāna literature for Śrāvakas and Pratyekabuddhas ${ }^{75}$ to hasten to reach nirvāna because they are terrified of samsāra, whereas Bodhisattvas ${ }^{76}$ remain in

59,24: nairātmyabhāvanāsātmye; PVṬ Je D251a1-2/P298a2 $\approx$ PVSVṬ 399,25: sātmībhūtam mārgam; PVP D89b1/P103a5: lam de‘i bdag ñid can gyi sems; PVV 83,14-15: sātmībhūtamārge. Note Devendrabuddhi's definition of mārga at PVP D89b3/P103a8: bdag med pa ñid mthon ba'i mtshan ñid can gyi lam (cf. PVV 83,11: nairātmyadarśanasya mārgas[ya]). Note also PVṬ Ñe D133a6-7/P164a7-8: dinos po ji ltar gnas pa bźin du 'dzin pas źugs pa'i bdag med pa'i lam ni sems kyi rañ bźin ñid yin pa'i phyir ro $\|$.

71 PVP D58a7-b2/P66b3-6 and D58a2-4/P66a4-6: bdag med pa ñid mthon ba lhun gyis grub pa'i skyes bu.

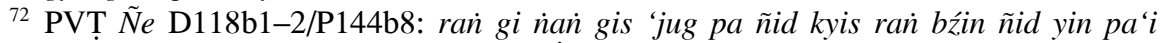
phyir ro \|. Note also TSP K895,8-9/Ś1082,22-23: ... iti svabhāvatvena prajñād̄nām sakṛāhitānām svarasata eva pravṛttir bhavatīti siddham |.

${ }^{73}$ PV 2.197-198: nāmuktih pūrvasamsskārakșaye 'nyāpratisandhitah | akșịnaśaktih samskāro yeșām tị̦țanti te 'naghāh $\|$ mandatvāt karunāyāś ca na yatnaḥ sthāpane mahān | tișthanty eva parādhīnā yeșạ̣̄ tu mahatī krpā $\|$.

74 According to PVP D85a1/P97b3-4: gal te chags pa med pa dag sñin ries gnas pa de $i$ tshe sñin rje[s] gnas nas sems can gyi don yid la byas nas de dag yun rin por ci' $i$ phyir mi gnas $\mid$. See also the prayoga that follows (PVP D85a1-3/P97b4-6).

75 PVP D85a3/P97b7: dper na ñan thos dan ran் sañs rgyas dag lta bu'o \|. PVV 79,11: śrāvakānān tu karmaṇo niyatakālasthitikadehākṣepakatvāt.

${ }^{76}$ PVP D84b7/P97b3: dper na byan் chub sems dpa' rnams kyi lta bu'o \|. Note, however, Manorathanandin's (PVV 79,10) explanation of anaghāh as samyaksambuddhāh. 
samsāra in order to honour their commitment to alleviate living beings' suffering. ${ }^{77}$ Though these Bodhisattvas are dispassionate (vìtarāga?) and "endowed" with an undefiled (nirdosa?) series of aggregates (skandhasantati?), ${ }^{78}$ the force of their karmic impulses is unexhausted ${ }^{79}$ "because all [their] provisions [of merit and knowledge] result in unfixed nirvāṇa (*sarvasambhārasya apratișthitanirvāṇaphalatvāt)." Because of his great compassion, a Bodhisattva does not remain in nirvāna (unlike Śrāvakas and Pratyekabuddhas), and because of his insight or wisdom, he does not remain in samsāra either (unlike ordinary people). ${ }^{80}$ As Devendrabuddhi puts it, ${ }^{81}$ "the reason why these great beings (mahāsattva) who are extremely affectionate without any [selfish] motive (akāranaparamavatsala) remain uninterruptedly [in samsāra] is [their] great compassion (mahatī krpāa), which proceeds spontaneously (svarasavāhin), because its practice (krpābhyāsa) is preceded by the thought of enlightenment (bodhicittapūrvaka)."

3.5. Áśrayaparivrtti and Buddhahood. The practice of the path ends with the so-called transmutation of the basis [of personal existence] ${ }^{82}$ (āśrayaparivrtti), which, like Vasubandhu (the Kośakāra), Dharmakīrti interprets (only in PV 2!) from a Sautrāntika perspective as the final and irreversible elimination (niranvayavināsa) of defilements together

77 See BoBh D27,9-28,6/W40,3-41,12, TSP K872,1-7/Ś1055,14-10, and Eltschinger (forthcoming 1, §2.6).

${ }^{78}$ See PVT N Ne D131b2/P162a1-2: gan் 'du byed nus zad med can źes bya ba ni phun po 'i rgyun skyon med pa skyed pa la |'dod chags dan bral ba gan dag la las kyi nus pa zad pa med pa yod pa źes bya ba'i don to $\|$.

79 According to PVT $\tilde{N}$ e D131b2-3/P162a2-3: [dper na byan chub sems dpa' rnams kyi lta bu'o źes bya ba ni byan் chub sems dpa' rnams ni las kyi nus pa zad pa can ma yin te |] tshogs thams cad mi gnas pa'i mya nan las 'das pa' $i$ 'bras bu can ñid yin pa'i phyir ro $\|$.

80 See MSAVBh D63b5-64a4, and Eltschinger (2008, n. 51).

${ }^{81}$ According to PVP D85a4-6/P98a1-2: gan dag sems can chen po rgyu med par mchog tu mñes gśin pa byan chub kyi sems síon du son ba can gyi brtse ba goms pa'i stobs kyis ran gi nan gis 'jug pa' $i$ brtse ba chen po rgyun mi 'chad par gnas pa' $i$ rgyu mía 'ba [de dag gźan gyi nor ni bźugs pa yin | sems can gyi don gyi phyir |dus thams cad du bźugs pa ... ] Note PVV 79,15: yeșām akāranavatsalānām mahatī krpāa as well as PVV 79,9: yeșām punar mahākrpāṇām pranidhānaparipuṣtasya ...

${ }^{82}$ PV 2.205ab: ukto mārgas tadabhyāsād āśrayah parivartate $\mid$. 
with their (productive) latent tendencies or germs $(b \overline{i j} a){ }^{83}$ Whereas this (minimal) definition seems to be true of all the Buddhist liberated minds whatsoever, it must be considerably enlarged when regarding the transmutated basis of the Bodhisattva who has just (i.e., ipso facto) become a Buddha/Sugata. Dharmakīti first spells this out in PV 2.135$136 \mathrm{ab}^{84}$ : "The qualities and drawbacks of the [perception of unsubstantiality and its opposite] become [perfectly] clear to the [Bodhisattva] who practices the means [i.e., insight/discernment] repeatedly, in various ways and for a very long time. And because of the intensity the cognition [of unsubstantiality has reached] due to this [extremely long repetition of practice], the after-effect of the cause [of suffering] is abandoned." Because he sees in all clarity the qualities of the salvific means and the drawbacks of its opposite, the Buddha is able to instruct living beings in the path or the four noble truths, ${ }^{85}$ i.e., is possessed with śâstrtvasampad and conversion through the teaching (anuśāsaniprātihärya). ${ }^{86}$ But no less important here is the fact that, due to this nearly endless cultivation, the Bodhisattva has rid himself of the (nonproductive) trace or after-effect of defilements. This after-effect of defilements consists in a corporeal $\left(k \bar{a} y a^{\circ}\right)$, verbal $\left(v \bar{a} c^{\circ}\right)$ and mental $\left(\right.$ buddhi $i^{\circ}$ ) defectiveness (vaigunya) or unwieldiness (akarmanyatāa) ${ }^{87}$ This still affects liberated saints like the Arhat Maudgalyāyana, who kept hopping around because he had been born as a monkey 500 lifetimes earlier, or the Arhat Pilindavatsa who, because he had been a brāhmana before, continued to say harsh and belittling words to his

${ }^{83}$ On the āśrayaparivrtti in Dharmakīrti's works, see Eltschinger 2005b. Niranvayavināśadharman in PVSV 110,22, TSP K875,20/Ś1060,13, is explained by Śākyabuddhi and Karnakagomin (PVṬ Je D250a3-4/P296b5-7 = PVSVṬ 399,7-9) as follows: anvayah kleśabījam | anvety utpadyate 'smād doṣa iti krtvā | nirgato 'nvayo yasmin vināśe sa niranvayavināśah $\mid$ sa dharmo yeșām doṣānām te niranvayavināśadharmānah | vāsanayā saha vināśadharmāṇa ity arthah $\mid$. On Vasubandhu's views as regards äśrayaparivrtti, see Eltschinger 2005b: 181-182.

${ }^{84}$ PV 2.135-136ab: bahuśo bahudhopāyam kālena bahunāsya ca | gacchanty abhyasyatas tatra guṇadoṣāh prakāśatām \| buddheś ca pātavād dhetor vāsanātah prahīyate $\mid$.

85 As a tāyin or "protector" of the living beings (see PV 2.145-146ab).

${ }^{86}$ PVP D61a2-3/P69b5-7 (Eltschinger 2005a: 424). See Kośa 7.110-112 (Pruden 1991: IV.1166-1167).

${ }^{87}$ See PV 2.141c. 
fellow monks. ${ }^{88}$ In other words, the (Bodhisattva/)Buddha has eliminated the obstacle consisting of defilements together with their aftereffects (savāsanakleśāvarana). But yet another type of abandonment distinguishes him from Śrāvakas and Pratyekabuddhas: contrary to them (or to Arhats), a Buddha has rid himself of unskilfulness in teaching the path (mārgoktyapatutāa) ${ }^{89}$ which I interpret as Dharmakīrti's allusion to undefiled ignorance (aklisțāvidya $\bar{a}$, ajñāna, ${ }^{\circ}$ sammoha).${ }^{90}$ If this hypothesis holds good, we can safely consider our Bodhisattva's transmutation of the basis also to entail the elimination of the obstacle that conceals the knowable (jñeyāvarana, and hence an omniscience of the sarvasarvajñatā-type), for the equation aklisțāvidy $\bar{a}=j \tilde{n} e y \bar{a} v a r a n a$ is easy to document in Buddhist Mahāyāna literature. ${ }^{91}$ Moreover, most of the definitions of ásrayaparivrtti include the elimination of both obstacles, the epistemologists being no exception. ${ }^{92}$

\section{THE COGNITION OF A YOGIN}

\section{Yogijñāna as an Epistemological Topic}

Let us now turn to the epistemological dimension of yoga proper. ${ }^{93}$ Dharmakirti devotes two main passages to the so-called perception of

${ }^{88}$ On the vāsanāsamudghāta, see Lamotte 1974, Traité IV.1755-1758, and Eltschinger 2005a: 419-422. On the story of Maudgalyāyana, see PVT Ñ $e$ D118b45/P145a4-5, Lamotte 1973: II.300, Traité I.117n. 4 and Lamotte 1974: 92. On the story of Pilindavatsa, see PVT $\tilde{N} e$ D118b5-6/P145a5-7.

${ }^{89}$ See PV 2.141d.

${ }^{90}$ See AKBh 1,13-15 (Kośa 1.2, Pruden 1991: I.1-2), Jaini 2001: 167-179, Eltschinger 2005a: 423-424.

${ }^{91}$ See Eltschinger 2005a: 429-434.

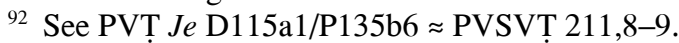

93 Among Buddhist philosophers, Dignāga (480-540?) is likely to have been the first one to discuss the perception of mystics within the general framework of perception (pratyakșa) as a means of valid cognition. However, the following statement seems to exhaust Dignāga's opinion on the subject: "[T]he yogin's intuition of a thing in itself unassociated (avyatibhinna) with the teacher's instruction [is also a type of perception]. The yogin's perception which is not associated (avyavakirna) with any conceptual construction of agama (the authoritative words of the teachers) and which apprehends only a thing in itself is also perception." Hattori's (1968: 27) translation of PS 1.6cd and PSV thereon. Sanskrit texts (< Vibh. 191n. 3 and 203n. 1) in Hattori 1968: 94 nn. 1.48 (yoginām gurunirdeśāvyatibhinnārthamātradṛk) and 
yogins (yogipratyaksa), ${ }^{94}$ both of which refer their reader back to the religious ideas we have considered so far, i.e., to the religious philosophy as expounded in PV 2. What do yoga and yogins consist of? Dharmottara (740-800) is one of the few authors to supply any substantial definitions of these two terms. According to ordinary understanding (loka), yoga consists of (psychic) concentration (samādhi), but according to (Buddhist) authoritative treatises (śāstra), it consists of tranquillity (of mind, śamatha) and discernment (vipaśyanā), which have (psychic) concentration and insight (prajñ $\bar{a})$ for their nature $\left({ }^{\circ} \bar{a} t m a n\right)$, respectively. A yogin is one who is possessed of tranquillity of mind and discernment into the nature of things, one who strives for constant concentration $(<$ nityasamāhita) and discrimination of true reality (tattvapravicaya?). ${ }^{95}$

1.49 (yoginām apy āgamavikalpāvyavakīrnam arthamātradarśanam pratyakșam). Steinkellner's reconstruction of PS(V) 1.6ab reads as follows: yoginām gurunirdeśāvyavakīnāirthamātradṛ|. Note that PSV is also quoted in PVP D210b3/P246b56. Interestingly enough, Dignāga's presentation is based on two notions the subsequent tradition will seemingly disregard. First, the perception of yogins grasps a "thing in itself" (arthamātra); this expression I do not dare interpret further than Jinendrabuddhi's comment to the effect that ${ }^{\circ}$ mätra ("only," "in itself" in Hattori's translation) aims at excluding superimposed objects (PST 56,15-57,1: mātraśabdo 'dhyāropitärthavyavacchedārthah |). Second, this perception is totally free from, or unmixed with scriptural concepts (ägamavikalpa), which on the one side matches the definitory non-conceptuality of perception well, but on the other side seems to conflict with the subsequent tradition's insistence upon the four Noble Truths (on this point, see Franco in present volume).

94 PV 3.281-286, PVin 1.27,7-28,8; see also NB 1.11. On yogipratyakșa, see Vetter 1964: 41, Steinkellner 1978, McDermott 1991, Pemwieser 1991: 21-50, Dreyfus 1997: 413-414.

95 According to the following passages: PVinT D117b2-3/P135b1-2: 'jig rten na ni mñam par gźag pa la rnal 'byor (em. 'byor: DP 'byor ba) yin la $\mid$ bstan bcos las ni tin ne 'dzin dan் śes rab kyi bdag ñid źi gnas dan lhag mthon la yin te | rnal 'byor ba de dag la yod pa de dag ni rnal 'byor bas te | rtag tu mñam par gźag pa dan்| de kho na rnam par 'byed pa la brtson pa'o \|. NBṬ S12,8-9/M70,2: yogah samādhih | sa yasyāsti sa yogī| ( PSṬ 56,12: yogah samādhih | sa yeșām asti, te yoginah $\mid)$, and DhPr 70,19-22 thereon: yogaśabdasya vyutpattim āha $\mid$ yoga iti $\mid$ samādhiś cittaikāgratā | iha dharmottareṇa lokaprasiddhir āśritāa | viniścayațīkāyām tu śāstrasthitis tenāvirodhah | yad vā samādhigrahanasyopalakșanatvāt prajñā ca vivekakaranaśaktir draștavyā | sa yasyāsti sa nityasamāhito vivekakaraṇatatparaś ca yogī|. PVA 327,17-18: tathā ca śamathavipaśyanāyuganaddhavāhī mārrgo yoga iti vacanam|. 
Let us start with Dharmakīrti's definition of perception in his PVin and NB, and disregard the possible evolution of his ideas on this topic (cf. Franco, forthcoming). In PVin $1.4 \mathrm{ab}_{1}$, Dharmakīrti defines perception as cognition that is free from conceptual thought (kalpana $\bar{a}^{-}$ podha) and is non-erroneous (abhrānta), ${ }^{96}$ conceptual thought being in turn characterized as a cognition whose appearance or image may be expressed verbally. ${ }^{97}$ We may thus offer two defining conditions that the cognition of a yogin must meet in order to be termed a "perception": first, it must be non-conceptual (and hence its content cannot be adequately expressed by words); second, it must be non-erroneous and reliable/non-belying (avisamvādin). The criterion of a given cognition's non-conceptual character lies in its presenting a clear or vivid (spașta, sphuta) appearance or image. The vividness and hence the non-conceptuality of a yogin's cognition comes from the fact that this cognition is born of cultivation (bhāvanāmaya, etc.) and arises out of this virtually endless process characterized as punah punar utpādanam, as we have seen above. ${ }^{98}$ Dharmakīrti spells this out as follows ${ }^{99}$ : "[We have already] presented the cognition of the yogins above [in the second chapter]. This [cognition] of the [yogins] is born of cultivation [and therefore is] free from the [deceptive] net of conceptual thought (kalpanā)[; because it is of a non-conceptual character, this cognition] presents a vivid image." This depiction is indeed the forerunner of Dharmakirti's opening statement on the subject in PVin 1, where the second definitory criterion has been duly integrated ${ }^{100}$ : "That cognition which, as in the case of fear, etc., vividly appears by force of cultivation, [and which is]

${ }^{96}$ PVin 1.4ab ${ }_{1}=$ NB 1.4: pratyakșam kalpanāpoḍham abhrāntam. Note also Dharmottara's (PVinT D117a4/P135a2-3) definition of pratyaksa in this context: gsal bar

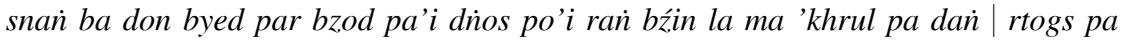
med pa'i śes pa ni minon sum yin no $\|$.

${ }^{97}$ PVin 1.7,7 $\approx$ NB 1.5: abhilāpasamsargayogyapratibhāsā pratītih kalpanā $\mid$.

98 See n. 57 above.

99 PV 3.281: prāg uktam yoginām jñānam teșām tad bhāvanāmayam | vidhūtakalpanājālam spaștam evāvabhāsate $\|$. To be connected with PV 3.285 = PVin 1.31: tasmād bhūtam abhūtam vā yad yad evātibhāvyate | bhāvanāparinișattau tat sphutăkalpadhīphalam \|. "Therefore, [be it] real or unreal, whatever is intensively meditated upon (atibhāvyate) results in a clear and non-conceptual cognition when the cultivation is perfected."

100 PVin 1.28: bhāvanābalatah spaștam bhayādāo iva bhāsate | yaj jñ̄anam avisaṃvādi tat pratyakșam akalpakam $\|$. 
reliable [as well as] non-conceptual (akalpa), this is a [direct] perception [too]." As Dharmottara has it, ${ }^{101}$ "due to cultivation, [this cognition] appears vividly; because it appears vividly, [this cognition] is established (siddha) as non-conceptual; since it bears upon an entity that has been 'purified' by the means of valid cognition (pramānapariśuddhavastuvisaya), [this cognition] is non-erroneous; therefore, why should it not be a perception, [if all] the other perceptions also appear vividly, are non-conceptual and non-erroneous?"

A cognition's being the outcome of the intense cultivation of an object by no means implies that the said cognition bears upon a real (bhüta) object (artha, visaya). Dharmakīrti adduces several examples in order to show that the cultivation of unreal (abhüta) objects may also result in a vivid and hence non-conceptual cognition. He says ${ }^{102}$ : "[People who are] deluded by confusion due to love, sorrow or fear, and by dreams about thieves, etc., ${ }^{103}$ see [the respective objects] as if [these would] stand before [them,] though [these objects are] unreal." But, one may ask, how do we know that these deluded persons see, because of their cultivation of it, the object as if it would stand before them? ${ }^{104}$ This is to be inferred on the basis of these persons' outward behaviour, as Dharmakīrti says ${ }^{105}$ : "Since we see that, in accord with the delusion

101 PVinṬ D117a7-b1/P135a7-b1: bsgoms pas gsal bar snañ źin | gsal bar snan ba'i phyir rnam par rtog pa med par grub pa yin la $\mid$ tshad mas yons su dag pa'i dinos po'i yul can yin pa'i phyir ma 'khrul pa yin pas ci'i phyir mion sum ñid du mi 'gyur|

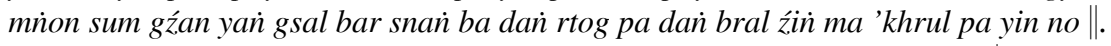

${ }^{102} \mathrm{PV} 3.282$ = PVin 1.29: kāmaśokabhayonmādacaurasvapnādyupaplutāh | abhūtān api paśyanti purato 'vasthitān iva $\|$. According to PVP D210b5/P247a1, this stanza

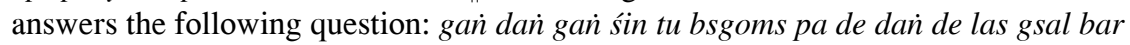
snañ bar 'gyur ro źes bya ba de ñid gan las yin źe na $\mid$.

103 PVP D210b7/P247a4 explains “etc." as: myur du bskor ba dan 'chi ltas la sogs pa gzun் no \|. See also PVT N Ne D215b6-7/P266b1-2 thereon: sogs pa smos pas ni myur du bskor ba dan் 'chi ltas la sogs pa gzun் ño źes bya ba la | 'di ltar 'khor lo bźin du lus myur du bskor ba las díos po g.yo ba med pa yan g.yo ba bźin du gsal bar dmigs par 'gyur ba 'an் 'chi ba'i dus na lus dan sems kyi gnas skabs 'ga' źig 'chi ltas kyi min can dinos po yan் dag pa ma yin pa mthon bar 'gyur ro $\|$.

104 PVinT D119a1/P137a4: yan de dag gis de mdun na gnas pa bźin du mthon ba źes bya ba 'di gan las śe na|.

105 PVin 1.30ab: yathāviplavam āvegapratipattipradarśanāt|. "To be inferred" according to Vibh. 203n. 3 (anumeya). Eli Franco kindly suggests to me that one can interpret this statement in a slightly different manner: ... since they show (their delusional) cognition by their agitation. 
[they are the victims of], they act with agitation." Some explanations may not be out of place. By "agitation" (āvega), we should understand physical states such as trembling with joy, or being thrilled (romaharșa). By "behaviour" is meant a physical action (anușthana) that conforms to the specific vision of a deluded person: the first will stretch his arms out in order to embrace his beloved, the second mourns or sighs, and the third boastfully seizes a sword. ${ }^{106}$ But one may also wonder why the cognition at stake should be of an immediate (pratyaksa) rather than of a mediate (paroksa) character. ${ }^{107}$ This Dharmakīrti answers as follows ${ }^{108}$ : "Because we do not see any behaviour of that kind when [someone] is conscious that his/her cognition is a mediate one (paroksa)."

However, cultivating unreal objects is by no means limited to deluded or passionate people. The Buddhist meditation exercises that build up, among other things, the (remote) preparatory path (prayoga$m \bar{a} r g a)$ are also endowed with utterly unreal objects, as Dharmakīrti tells us in both his PV and PVin ${ }^{109}$ : "We hold that, though [they are] unreal, the loathsome, the totality of earth, etc., which are created by force of cultivation, are vivid and [hence] non-conceptual." This includes meditation such as cognizing a corpse turning blue (vinīlaka) or rotting (vipüyaka), or of a corpse that has become a skeleton (asthi-

106 See PVinT D119a1-3/P137a4-6: gus pas ni grims pa ste | spro ba'i dban gis 'dar ba'i mtshan ñid can nam ba spu lañs mtshan ñid kyi lus kyi gnas skabs so \|bsgrub pa ni mthon ba dan rjes su mthun par nan tan du byed pa ste | sdug pa la sogs 'dren

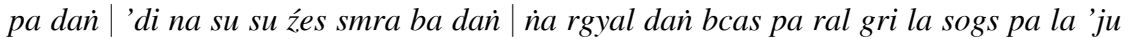
ba ste |. PVP D210b7-211a1/P247a5-6: de ltar na de ltar mthon bas don minon du gyur pa bźin du $\mid$ de dan rjes su mthun par bsgrubs pa la dmigs par 'gyur na $\mid$ gan gis na de dag 'dir lkog tu gyur pa'i min can du yan் 'gyur ba ma yin no źes bya ba de ñes par gzun் bar mi 'gyur|. PVV 203,9: yasmāt tadanurūpām pravrittị ceștante |.

107 According to PVinT D119a3/P137a6-7: 'di sñam du gus pas bsgrub pa mthon du zin kyan் $\mid$ mñon sum bźin du de dag gsal bar snañ ba yin par ji ltar ñes śe na $\mid$.

108 PVin 1.30cd: parokșagatisaṃjñāyām tathāvṛtter adarśanāt $\|$.

109 PV 3.284: aśubhāpṛthivīkrtsnāady abhūtam api varnyate| spașțābham nirvikalpam ca bhāvanābalanirmitam \|. PVin 1.28,7-8: tathā hy aśubhāprthivīkrtsnādikam abhūtavișayam api spaștapratibhāsam nirvikalpakam ca bhāvanābalaniṣpannam iṣyate ||. "It is indeed accepted [by us Buddhists] that [meditative exercises] like [the contemplation of] the loathsome and the totality of earth, which arise by force of cultivation, present a vivid image and are non-conceptual despite [their] having an unreal object." 
sankalā), ${ }^{110}$ or meditation that has all entities (vastu) appearing as the earth, or as water, as they have unreal objects despite the fact that the image they display is perfectly clear once the cultivation process has been completed. ${ }^{111}$ The reason why these meditations have unreal objects is, according to Vaibhāșikas and to Dharmottara, that they consist in acts of attention that are directed towards imaginary or, better, volitional objects (adhimuktimanas[i]kāra). ${ }^{112}$

Since they arise from intensive cultivation of their objects, the aforementioned direct or immediate cognitions display a vivid image and hence are non-conceptual. In this respect, they all meet the first defining condition of a perception. But since they bear upon imaginary or volitional objects such as a beloved, an enemy or a putrefying corpse, they fail to meet the second. As belying/unreliable (visamvādin, asamvādin) cognitions, they do not lay claim to the "validity" that is inherent in a true perception. As Dharmakīrti himself says, ${ }^{113}$ "among these [vivid and non-conceptual cognitions that result from cultivation, ${ }^{114}$ we] accept as a means of valid cognition [only] that perception which, born of cultivation, is reliable, ${ }^{115}$ just like [the one that is related

${ }^{110}$ See PVinT D119b2/P137b7: mi sdug pa źes bya ba ni rus pa 'brel pa'i rnam pa can gyi tỉn ìe 'dzin to \|, PVV 203,22: aśubhā vinīlakavipūyakāsthisañkalādikā. On aśubhā, see Kośa 6.148-153 (Pruden 1991: III.916-921).

111 PVinT D119b2-3/P137b7-8: zad par sa ni díos po mtha' dag sar snan் ba'i tì ìe 'dzin to \| sogs pa smos pas ni zad par chu la sogs pa'o \|, PVV 203,22: prthivikrtsnādi bhūmayatvādi. On krtsnāyatanas, see Kośa 8.213-215 (Pruden 1991: IV.1277-1278).

112 PVinT D119b4/P138a1-2: mos pas byas pa rnal 'byor ba'i spyod yul du 'gyur ba rus pa la sogs pa rnams ... On adhimuktimanas[i]kāra in the case of aśubhā, see Kośa 6.150 and 152 (Pruden 1991: III.918-919 and 920); on adhimuktimanas[i]kāra in the case of the krtsnāyatana, see Kośa 8.214n. 1 (Pruden 1991: IV.1306n. 203). About this meaning of adhimukti, see Bhsd 14b-15a s.v. adhimucyate (2). Note also Devendrabuddhi's (PVP D211b2-3/P248a1) explanation: rai gi rnam par rtog pa tsam gyis kun nas bslan ba yin no \| (*svavikalpamātreṇa samutthitāh), as well as Prajñākaragupta's (PVA 327,14): atattvamanaskāratvād aśubhādīnām.

113 PV 3.286: tatra pramānạn samvvādi yat prānnirṇîtavastuvat | tad bhāvanājạ̣ pratyakșam iștam śeșā upaplavāh $\|$.

114 According to PVV 204,9: tatra bhāvanābalabhāviṣu spașț[a]nirvikalpeṣu; PVP D211b4/P248a4: de sgom pa'i 'bras bu'i śes pa de dag la.

115 See PVV 204,9: samvāày upadarśitārthaprāpakam. 
to] the matter (vastu) [we] determined above [in chapter two]. All the remaining [cognitions] are [mere] delusions. ${ }^{16, "}$

The condition of a yogic cognition's reliability lies in its bearing on an object that has proved to stand critical analysis by means of pramānas. In other words, this object must have been submitted to rational inquiry (yukti), "purified" ([pari]śuddha) or ascertained as agreeing (samvādin) with the means of valid cognition. This is tantamount to saying that the object of a yogin's cognition is one that has been reflected upon $(<\sqrt{c i n t})$, examined $(<v i \sqrt{c a r})$ or ascertained $(<n i s i \sqrt{c} i$, vyava $\sqrt{s t h} \bar{a}_{\text {caus }}$, nir $\left.\sqrt{n} \bar{l}\right)$ by means of the above-mentioned cintamay $\bar{\imath}$ praj $\tilde{n} \bar{a}$. It is obvious that, as Dharmakīrti himself makes clear, this object only consists of the four Noble Truths ${ }^{117}$ that he submitted to inferential evaluation in the second chapter of his PV. ${ }^{118}$ When commenting on Dharmakirti's statement to the effect that yogic cognition has already been treated, all commentators add that it has been explained "as bearing upon the (four Noble) Truths" ([caturārya]satyavisaya), and this in the satyavicāracintā of the Pramānasiddhi chapter. ${ }^{19}$ In other

116 PVP D211b5/P248a5: dper na zad par sa la sogs pa lta bu'o \|; PVV 204,13-14: śeșā ayathārthā upaplavā bhramā yathā aśubhāprthivīkrtsnādipratyayāh $\mid$.

117 See PVinT D118a2-3/P136a2-4 for a short summary on the four Truths: 'bras bur gyur pa ñe bar len pa'i phun po lina ni sdug bsnal lo $\|$ de dag ñid sred pa dan lhan cig pas rgyur gyur pa ni kun 'byun் no $\|$ nes par legs pa'i ran bźin du gyur pa'i sems ni 'gog pa'o $\|$ ran bźin de ñid thob pa'i rgyur gyur pa bdag med pa la sogs pa'i rnam pa can gyi sems kyi khyad par ni lam mo \|. "Suffering (duhkha) consists of the resultant (phalabhüta) five constituents[-of-a-person] which one clings to (pañca upādānaskandhāh). The origin (samudaya) [of suffering] consists of the same [five constituents] with the status of a cause (hetubhüta) because [they are] accompanied by craving (trṣnāsahita?). The destruction (nirodha) [of suffering, i.e., nirvāna,] consists of the mind (citta) having turned into a blissful condition (nihśreyasasvabhāvabhüta?). The path (mārga) [that leads to the destruction of suffering] consists of a particular mind (cittaviśeșa?) which, endowed with such [real] aspects as unsubstantiality (nairātmyādyākāra[vat]?), is the cause of obtaining this very condition (tasya eva svabhāvasya prāptihetubhūtah??) [that defines nirvāna]."

118 PV 3.286b: prānnirn̄itavastuvat; PVin 1.27,11-12: āryasatyadarśanavad yathā nirṇitam asmābhih pramānavārttike; note also PV 3.281a: prāg uktạn yoginām jūānam.

119 On PV 3.281a: PVV 203,1: prāk prathamaparicchede (= Pramānasiddhi) yoginām jñānam satyavișayam uktam; PVA 326,23: caturāryasatyavișayam yoginām jñānam prāg uktam; PVP D210b3-4/P246b6-7: snar bśad rnal 'byor śes pa ni snar 'phags pa'i bden pa bzi'i yul can du bśad pa na | bden pa dpyod pa gan yin pa de źes bya ba'i don to ||. On PV 3.286b: PVV 204,12-13: prāk prathamaparicchede nirṇitam 
words, as Devendrabuddhi has it, ${ }^{120}$ "not all cognitions of yogins are perception (pratyaksa), but (kim tarhi) [only] the one that has been stated before, i.e., the one that has been stated before as bearing upon the four Noble Truths." According to Dharmottara, ${ }^{121}$ "the cognition that perceives (darśana) these [four Noble Truths], i.e., is aware of them in immediate manner (sāksât ${ }^{\circ}$ pratyakșikarana), is perception (pratyaksa)." And according to the same author, ${ }^{122}$ Dharmakīti in his PV has explained "how the four Noble Truths are 'purified' by pramānas, and how they are to be cultivated (bhāvanīya) under such aspects as impermanence (anityādi)." Now provided a yogin's cultivational and hence non-conceptual cognition has the four Noble Truths for its object, it meets the second defining condition of a perception.

vastu satyacatuṣtayam tasminn eva; PVA 327,32-33: prān்nirṇītavastu paralokacaturāryasatyādikạ̣ tadvișayam eva pratyakșam | na tu kāmāadivișayam |; PVP D211b5/P248a5: snar bden pa dpyad pa'i skabs su tshad ma'i dinos po yan dag par bstan pa bźin no. Note also NBT S11,18/M67,3-4: bhütah sadbhūto 'rthah | pramānena dṛsțaś ca sadbhūtah | yathā catvāry āryasatyāni |, and PVV 203,2 (satyasvarūpavișaya) or 204,3 (āryasatyādi as a gloss on bhütam). Prajñākaragupta's paraloka is the only exception I am aware of in this particular context. The presence of an "etc." ( $\left.{ }^{\circ} a d i\right)$ is no argument since most if not all ${ }^{\circ} \bar{a} d i$ s are explicable or even explained as nairātmya or anitya[tā], which of course amounts to the four Noble Truths (note also that Dharmakīrti does not introduce an ${ }^{\circ} \bar{a} d i$ in this particular context).

${ }^{120}$ PVP D210b3-4/P246b6-7: rnal 'byor ba'i śes pa thams cad minon sum ma yin no $\|$ 'o na ci yin źe na | snar bśad rnal 'byor śes pa ni [= PV 3.281a] | snar 'phags pa'i bden pa bzi'i yul can du bśad pa na|.

${ }^{121}$ PVinT D118a3-4/P136a4-5: 'di [= bden pa] dag mthon bar mn்on sum du byed pa'i śes pa gan yin pa de míon sum yin pa|.

122 PVinT D118a4/P136a5: 'phags pa'i bden pa bźi po rnams ji ltar tshad mas rnam par dag pa dan | mi rtag pa la sogs pa de dag rnam pa ji lta bu bsgom par bya ba. Note the whole of Dharmottara's account of Dharmakīti's PV 2 (PVinT D118a46/P136a5-8): 'phags pa'i bden pa bźi po rnams ji ltar tshad mas rnam par dag pa dan $\mid$ mi (D:P bi) rtag pa la sogs pa de dag rnam pa ji lta bu źig (D:P om. źig) bsgom par bya ba dan $\mid$ skye ba brgyud pa du mas dus ji srid kyi mthar thug par goms par

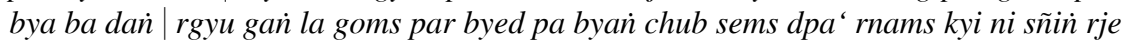
las yin la | de las gźan rnams ni 'khor ba las yid byun ba źes bya ba gan yin pa de thams cad ni |ji ltar Tshad ma rnam 'grel du gtan (D:P bstan) la phab pa'i rnam pa de ñid kyis 'phags pa'i bden pa mthon ba thabs dan bcas $\mid$ yul dan bcas | rnam pa dan bcas par khon் du chud par byas te | 'dir ni yan dag pa 'i yul can gyi rnam par rtog pa goms pa las de 'i don la dmigs pa'i mñon sum skye ba ñid do źes bya ba de tsam źig bsgrub (P:D bsgrubs) par 'dod pa 'ba' źig tu zad do $\|$. 
In a most interesting statement of the PVin, Dharmakirti relates the topic of yogijñana back to the basic path-structure of Buddhism. The traditional threefold sequence or gradual progression (bhāvanākrama) of insights is deemed to be the cause of a yogic cognition's vividness and reliability ${ }^{123}$ : "Having first grasped objects through a cognition born of listening [to treatises that are favourable to cultivation ${ }^{124}$ ], and [then] ascertained [them] through a [cognition] born of reflecting [upon them] by means of rational inquiry (yukti) [i.e., by means of pramānas], ${ }^{125}$ yogins cultivate [those objects]. The [cognition] which, at the completion of this [cultivation], appears as vividly as in such cases as fear [or sorrow, and hence is] non-conceptual [but which also] has a true object [because it bears upon an object that has been formerly ascertained by pramānas], this is [also] the pramāna perception."

Note should be made in this connection that the cognition at stake is said to be "born of cultivation" (bhāvanāmaya), which the commentators explain as "caused by cultivation" (bhāvanāhetu[niṣpatti] ka), ${ }^{126}$ an expression that matches Dharmakīrti's own formulations well (bhāvanāja, bhāvanābalanirmita, bhāvanābalanișpanna, bhāvanābalata $\left.{ }^{127}\right)$. In other words, this cognition does not consist in cultivation, but arises at the very end of cultivation, once the cultivation proc-

${ }^{123}$ PVin 1.27,7-8: yoginām api śrutamayena jūānenārthān gṛītvā yukticintāmayena vyavasthāpya bhāvayatām tanniṣpattau yat spaștāvabhāsi bhayādāv iva, tad avikalpakam avitathavișayam pramānam pratyakșam. Dharmottara's introduction (PVinT D117b1-2/P135b1) runs as follows: 'di ñid rnam par 'grel pa na gsal bar snan ba ñid kyi rgyu bsgom pa'i go rim ston par byed do $\|$.

124 See PVinT D117b3-4/P135b3-4: thos pa las byun bas bsgoms pa dan rjes su mthun pa'i bstan bcos mñan pa'i rgyu can gyis bzun ba nes pa'i don bsgom par bya ba|.

125 See PVinT D117b4/P135b4: rigs pas te tshad mas sems śin nes par rog pa ni rigs pas (em. pas: DP pa) sems pa'o $\|$.

126 PVA 326,23-24: bhāvanāhetukam; PVV 203,1-2: bhāvanāhetunispattikam.

127 Respectively, PV 3.286c (bhāvanāja also PVV 203,10, PVV 204,10); PV 3.284d; PVin 1.28,8; PVin 1.28a (see also PVinT D117a5/P135a4 and D119b3/P138a1, where stobs is explained as mthu; PVP D211b4/P248a3; bhāvanābalāt PVV 327,8 and PVA 328,1). The commentators provide us with plenty of expressions: bsgoms pa'i stobs las skyes pa (PVP D211b1/P247b7-8), bhāvanābalaja (PVV 203,18 and 204,13), bhāvanābalabhāvin (PVA 327,32), bsgoms pa'i 'bras bu'i śes pa (PVP D211b4/P248a4, PVinT D119a7/P137b4 and D119b1/P137b6), bsgoms pa'i mthu las (PVinT D119b5/P138a3). 
ess has been completed (bhāvanāparinispattau, tannispattau ${ }^{128}$ ). This is indeed the way Dharmakirti accounts for yogijñanna in the definition he supplies in his $\mathrm{NB}^{129}$ : "Arisen from the ultimate degree [reached by] the cultivation of a real object, the cognition of yogins, too[, is a direct perception]."

\section{Yogijñāna in a Soteriological Perspective}

5.1. Dharmakīti repeatedly reminds his readers of the fact that he has already accounted for yoginām jūannam in the second chapter of his PV. This remark is a little puzzling insofar as this chapter does not provide any explicit treatment of the topic. Nevertheless, I think it supplies enough materials for us to proceed further in our interpretation of the yogin's cognition.

It is my contention that Dharmakirti's account of the yogin's cognition as vivid, non-conceptual and non-belying refers to the mind's gnoseological condition at the end of the "cleansing" path, i.e., at the moment when all superimpositions and their concomitant defilements, even those of an extremely subtle nature, have been thoroughly and absolutely eliminated. In other words, Dharmakirti's presentation concerns the mind or cognition of the mystic whose basis-of-existence has just been transmuted. The coincidence between Dharmakīrti's bhāvanāparinispattau in the context of yogijñanna and his remark to the effect that the basis-of-existence is transmuted due to the repeated practice of the path (tadabhyāsatt), is striking. It is brought out with particular clar-

${ }^{128}$ PV 3.285c = PVin 1.31c (note PVV 204,4-5: bhāvanāyāh sādaranirantaradīrghakālapravartitāyāh parinispattau); PVin 1.27,10 (sgom pa rdzogs śin PVinṬ D117b5/P135b5). Note also Devendrabuddhi's explanation of bhāvanāmaya as bden pa sgom pa rdzogs pa las (PVP D210b4/P246b7-8), as well as Dharmottara's bsgoms pa mthar phyin pa (PVinṬ D119a6/P137b3). The process traditionally ends up with or culminates in the so-called "absorption similar to a diamond" (vajropamasamādhi, see AKBh 364,13-365,10 [Kośa 6.227-229, Pruden 1991: III.981983]). This final moment in the path of cultivation marks the end of the "cleansing" process. I hold it to coincide with Dharmakīrti's bhāvanāprakarșaparyanta (NB 1.11), or with his bhāvanāparinispatti (PV 3.285c).

129 NB 1.11: bhūtārthabhāvanāprakarșaparyantajaṃ yogijñānam ceti \|. Dharmottara interprets ${ }^{\circ}$ paryanta $^{\circ}$ as ablative case (NBT S11,23/M68,2: tasmāt paryantāt yaj jātam), contrary to Jñānaśrīmitra's locative (bhāvanāprakarșaparyante, in Steinkellner 1978: 130n. 42). 
ity in Devendrabuddhi's commentary ${ }^{130}$ : "Due to the [repeated] practice $(a b h y \bar{a} s a)$ of the [aforementioned] path (mārga), i.e., once the cultivation (bhāvanā) of the path defined as the perception of unsubstantiality (nairätmyadarśanalakșana) has been completed (nișatti), the basis[-ofexistence] is transmuted (aśrayah parivartate, $=$ PV 2.205b): the defiled (dosavat?) mind (citta) [now] has the property (dharma) absolutely [never] to [re]arise (atyantānutpatti?). The meaning (artha) [intended by Dharmakīrti is the following]: the mind is [now] coessential with the path (mārgasātmani sthitam)." Highly interesting in this connection is an allegedly Vaibhāṣika objection occurring in Prajñākaragupta's PVA. Just before he turns to his criticism, the Vaibhāsika opponent concedes the following point: ${ }^{131}$ "It is true that [the cognition in question] presents, due to [intense] cultivation, a vivid image of an object (vastu) that has been [previously] established by the means of valid cognition, because [in it] the object (artha) appears in its own [particular] form (svena rūpena) when the opacity of nescience (avidyākālussya) has been [entirely] wiped away through cultivation." I conjecture that the doctrine that provokes the Vaibhāsika's assent encapsulates Dharmakirti's position with regard to the cognition of yogins. As we shall see, this hypothesis accounts both for the vividness and for the truth that are deemed inherent in a yogin's cognition.

5.2. In the second chapter of his PV, Dharmakīti presents us with the following "realist" account of the nature (prakrti) of cognition ( $v i$ jūana ${ }^{132}$ : "[Provided one accepts, unlike the idealist, ${ }^{133}$ that] the property of [all] cognition is to grasp an object, [one must also admit that]

${ }^{130}$ PVP D87a4-5/P100a7-b1: lam de goms pa las bdag med pa mthon ba'i mtshan ñid can gyi lam de'i sgom pa rdzogs pa na rten ni yons su gyur par 'gyur | ñes pa dan bcas pa'i sems śin tu skye ba med pa'i chos can yod na lam de'i bdag ñid la sems gnas par 'gyur ro źes bya ba'i don to $\|$.

131 PVA 327,8-9: (vaibhāṣikā āhuh | nanu) vastuni pramāṇaprasiddhe bhāvanābalāt spaștābhateti yuktam | bhāvanayāvidyākāluṣyāpagame svena rūpenārthasya pratibhāsanāt|.

132 PV 2.206-207a $\mathrm{a}_{1}$ : viṣayagrahaṇạ̣ dharmo vijñānasya yathāsti sah | gṛhyate so 'sya janako vidyamānātmaneti ca $\|$ eșā prakrtị ...

133 On the epistemological presuppositions of that passage, see PVP D87b588a4/P101a3-b3 (Eltschinger 2005b: 185-186), and TSP K872,27873,7/Ś1056,21-25 (McClintock 2002: 213-214). 
this [object] is grasped as it [really] is [i.e., as impermanent, etc. ${ }^{134}$ ]. This [object] generates this [cognition of itself] by [its] existing nature (vidyamānātmanā). And this is [the object's and the cognition's original] nature [i.e., that the object generates a cognition that grasps it as it really is, and that the cognition grasps a real aspect of the object]." Dharmakīrti's presentation relies on a Sautrāntika doctrine, according to which direct perception is explained by the fact that the object casts or "projects" (arpana) its own aspect (ākâra) and hence generates the cognition itself. Dharmakīrti spells this out in the third chapter of the same work ${ }^{135}$ : "Experts on rational inquiry consider that to be an object/be perceptible consists in being a cause [which is] capable of projecting a [true] aspect [of itself] onto the cognition." I believe we are left with no other possibility than to accept the alleged reality of the aspects the entity casts onto consciousness. As Devendrabuddhi makes clear, ${ }^{136}$ these real aspects are those we already met in Dharmakīrti's description of the sixteen aspects of the four Noble Truths, impermanence, painfulness, emptiness, selflessness, etc. The conclusion is then easily drawn, as Kamalaśîla has it $^{137}$ : "It has been settled that the original nature of the [mind/cognition] is to grasp the real aspects of the object. It has also been explained that the real nature of the object consists in momentariness, selflessness, etc. Therefore, [the mind] has but the grasping of unsubstantiality for its nature." In order to present us with the nature of cognition, the epistemologists resort to, and reinterpret accordingly, two highly valued traditional topoi, i.e., the alleged natural "luminosity" (prakrtiprabhāsvaratā) of the mind or cognition, ${ }^{138}$ and the perception of true reality (tattvadarśana). Dharmakīti describes the first in PV 2.208ab ${ }^{139}$ : "[Therefore,] the mind is radiant by [its very] nature [i.e., grasps an object as it really is, ${ }^{140}$ whereas] impurities (mala)

\footnotetext{
134 Anityādyākāra in PVP D87b6/P101a4, D88b3-4/P102a4-5.

135 PV $3.247 b_{2} \mathrm{~d}$ : grāhyatām viduh | hetutvam eva yuktijñā jūānākārārpanakṣamam $\|$.

136 See PVP D88a4-5/P101b3-4.

137 TSP K873,5-7/Ś1057,2-4: bhūtavișayākāragrāhitā asya svabhāvo nija iti sthitam bhūtaś ca svabhāvo viṣayasya kṣaṇikānātmādirūpa iti pratipāditam etat | tena nairàtmyagrahanasvabhāvam eva.

138 See Eltschinger 2005b: 180 and 190-192. On the mind's natural luminosity, see Seyfort Ruegg 1969: 410-454 and Lamotte 1987a: 51-60.

139 PV 2.208ab: prabhāsvaram idam cittam prakrtyāgantavo malāh $\mid$.

140 According to PVP D89a5/P103a1: 'di'i rà bźin 'od gsal te | yan dag pa ji lta ba bźin du 'dzin pa'i rañ bźin no $\|$.
} 
[such as the view of self or craving] are [purely] adventitious [i.e., are not its nature, ${ }^{141}$ and hence are removable]." According to the second topos, which, as far as I can see, Dharmakīrti does not explicitly allude to in this particular context, to see the real aspects of things amounts to perceiving true reality. Thus, Devendrabuddhi ${ }^{142}$ : "By its [very] nature, the mind thus consists of the perception of true reality, [whereas] impurities are [merely] adventitious." Or, as Śāntarakșita has it, ${ }^{143}$ "the mind, which consists of the perception of true reality, is radiant [by its very nature]."

Now how are we to account for the indisputable fact that we actually do not perceive true reality, i.e., do not perceive real entities as impermanent, painful, empty or selfless? In other words, how is it that we ordinary persons can at best infer these real aspects of things, and hence have but conceptual and nonvivid notions of them? Dharmakirti's answer is as follows ${ }^{144}$ : "On account of a certain cause (nimitta) [i.e., on account of an adventitious cause of error], the [mind] shifts (skhalat) from this [inherently veracious nature, superimposing such erroneous aspects as permanence on the object, ${ }^{145}$ ] and becomes uncertain (adr$(h a)$, requiring a condition ${ }^{146}$ (pratyaya) for the removal [of this state], like the cognition of a piece of rope [as a snake]." In order to understand the first part of Dharmakīrti's explanation, we should remember what the state of an ordinary person consists of. The innate false view

141 According to PVP D89a6/P103a2: glo bur ba yin gyi de ‘i ran bźin ni ma yin no \|.

142 PVP D89b1/P103a5-6: 'di ltar sems ni ṅo bo ñid kyis de kho na ñid mthon ba'i bdag ñid can yin la $\mid$ dri ma rnams ni glo bur ba yin pa. See also PVP D89b2/P103a7: sems kyi de kho na ñid mthon ba de'i bdag ñid can; PVP D87b4/P101a1: sems kyi ran் bźin ñid kyi de kho na ñid mthon ba de'i bdag ñid can; TSP K895,10/Ś1083,11: tattvadarśanātmakam eva vijñānasya (sic); TSP K895,7/Ś1082,21: prakrtyā tattvadarśanātmakatayā cittasya; TSP K895,19/Ś1083,15-16: tattvadarśanātmakam eva cittam siddham iti bhāvah; TSP K896,4 (with no equivalent in Ś!): tattvadarśin; PVV 107,6: tattvadarśitvāt (said of the Blessed One); PVV 107,5-6: atattvadarśinah (said of the vìtarāgā bāhyāh).

143 TS $343 \dot{5}_{\mathrm{K}} / 3434_{\hat{s}}$ : prabhāsvaram idạ̣ cittam tattvadarśanasātmakam |.

144 PV $2.207 \mathrm{a}_{2} \mathrm{~d}$ : asyās tan nimittāntaratah skhalat | vyāvṛttau pratyayāpekșam adṛ̣̂am sarpabuddhivat $\|$.

145 According to PVP D89a2/P102b4-5: rtag pa la sogs pa'i rnam par sgro 'dogs pas 'jug pa ni gźan du gyur pa'o $\|$ (where gźan du gyur pa is the Tibetan rendering of Sanskrit skhalat [/skhalana $]$ ).

${ }_{146}$ PVP D89a2-3/P102b5-6: rkyen la ltos pa yin te | de ltar skyes bu'i 'khrul pa gnod pa can gyi tshad ma la ltos pa dan் bcas pa yin no $\|$. 
of self, i.e., nescience, causes prthagjanas to superimpose sixteen unreal aspects onto the four Noble Truths, e.g., permanence, pleasantness, mine and I. Because they are attached to I and mine, or to self and one's own, ordinary beings crave for objects that delight the (pseudo-)self, and act accordingly in order to grasp them; they also develop aversion of whatever is deemed a threat to the self or its alleged property. Thus defilements and depravities arise out of the false view of self. ${ }^{147}$ This is the situation that Dharmakīrti alludes to when he says that the mind or the cognition shifts from its own true nature. ${ }^{148}$ But, as Dharmakirti has it, this superimposing cognition is as uncertain or unsteady as the mistaken cognition of a piece of rope as snake at night in a place where one may suspect the presence of snakes. ${ }^{149}$ In the same way, nescience and the superimpositions it is responsible for, no matter how deeply rooted in the mind, are removable because they are adventitious or unnatural to the mind. Now what is needed to get rid of this shift? The epistemologists' answer is unambiguous: an ordinary person who is deluded by the false view of self must resort to the means of valid cognition and especially to inference. Here again we should remember that, still as an ordinary person, one may, on account of belonging to a specific "family" and/or having met a "spiritual friend" like a Buddha or an advanced Bodhisattva, listen to the Buddhist scriptures and hence develop faith or conviction (adhimukti), but one may also set about rationally reflecting upon scriptural contents by means of pramānas. This rational inquiry, mainly consisting of the ascertainment of the true aspects of the Noble

${ }^{147}$ See $\$ \S 1.1-3$ above.

148 We should, however, be cautious not to ascribe to him the mythological notion of a "fall" or decay of the mind that would in turn imply the path to consist in the gradual recovery of a lost condition. Nescience is a beginningless (anādi) erroneous perception (mithyopalabdhi) that arises out of its own seeds (bija) or latent tendencies $(v \bar{a} s a n \bar{a})$ and that has been nourished by, and nourishes in turn, the so-called incorrect judgement (ayoniśomanaskāra). On this last doctrinal point, see PVSV 8,20-21 (ātmātmīyābhiniveśapūrvakā hi rāgādayo 'yoniśomanaskārapūrvakatvāt sarvadoșotpatteh |), PVṬ Je D249b6-7/P296a6-7 $\approx$ PVSVṬ 398,25-26, PVṬ Je D253a45/P301a4 = PVSVṬ 403,8-9, PVV 101,10 and 367,10-11. On ayoniśomanaskāra as the root of satkāyadrsțti, see MS 2.20.9 in Lamotte 1973: II.115, Paramārthagāthā 20 in Wayman 1961: 170, BhK 1.215,8-15.

149 See PVP D87b7/P101a6: dper na sbrul du 'dris pa'i phyogs mi gsal bar thag pa la sbrul gyi śes pa lta bu'o \|. Cf. Vibh. 82n. 4: (mandamandaprakāśe) sarpopacite pradeśe. See also Lamotte 1973: II.109-110, and MS 3.8.2 in Lamotte 1973: II.163. 
Truths, aims at shaping the salvational means (upāya), i.e., the perception of unsubstantiality as an antagonistic or opposing factor of satkāyadrșți. There can be no doubt that Dharmakīrti's vyāvrttau pratyayäpeksam (PV 2.207c) refers in the first place to the inferential analysis that is typical for the cintāmaȳ prajñ $\bar{a} .{ }^{150}$

As we have seen above, the cultivation of the salvational means that the yogin carries out is simultaneously of a cognitive and cleansing character. The more our yogin sharpens his realization of the Truths and their corresponding aspects, the more he succeeds in uprooting the opposite false views as well as the superimpositions and defilements they are responsible for. But eradicating the adventitious impurities amounts to gradually freeing the mind of those malignant obstacles that prevented it from grasping the object as it really is, i.e., with its real aspects of impermanence, emptiness, etc. During the path of vision, the yogin gets rid of gross superimpositions such as those the speculative false view of self gives rise to. Much more difficult to eliminate however, is the innate false view of self, along with the remaining defilements (i.e., the bhāvanāheyakleśas) and their productive and nonproductive vāsanās, the uprooting of which, in many Mahāyānist accounts, necessitates no less than eight complete stages or bhümis $(b h \bar{u}-$ mis 2-9). During the first six of these bhümis (2-7), the yogin must devote constant effort and "intentionality" (vikalpa) to his cultivation of the cleansing means; during the last two bhümis (8-9), insight becomes spontaneous, effortless, and unintentional. The removal of the most subtle categories of bad dispositions now proceeds as "automatically" or "naturally" as the perception of unsubstantiality itself. At the end of the path of cultivation, the entire filth of impurities has been irreversibly destroyed, a psychological and existential situation described as a transmutation of the basis-of-existence. Now the mind only consists of the path; it has the perception of unsubstantiality or discernment for its unique and indestructible nature. Dharmakîrti describes this as follows ${ }^{151}$ : "Of [these impurities] that were incapable [of annulling the mind] before [the perceptual realization of unsubstantiality ${ }^{152}$ ], what $(k v a)$ [could] therefore be the capacity afterwards, with regard to a [mind] that [once the practice of nairātmyadarśana has been completed,

\footnotetext{
${ }^{150}$ See $\$ \S 2.1-2$ above.

151 PV 2.208cd: tat prāg apy asamarthānām paścāc chaktih kva tanmaye $\|$.

152 According to PVP D89a6/P103a3: bdag med pa mthon ba'i mn்on sum du byas pa.
} 
entirely] consists (maya) of the [path] ${ }^{153}$ ?" The following excerpt of Devendrabuddhi will provide a useful summary as well as transition to the concluding part of my hypothesis ${ }^{154}$ : "[Moral] faults [i.e., defilements,] lack the capacity to re-occur in the mind of the one who is of one essence with the path (mārgasātmye sthitasya), for the nature (svabhāva) of the mind (citta) consists in the perception of true reality (tattvadarśanātmaka); ${ }^{155}$ it does not have for its essence the [moral] faults that are bound to [i.e., derive from] aspects that are contrary ( $v i$ parîtākära) [to the ones which are ascertained by the means of valid cognition]. Now its (= the mind's) depravities (upakleśa) [arise] by force of a [purely] adventitious condition (ägantu[ka]pratyayavaśát?). ${ }^{156}$ If something opposes $(\sqrt{b} \bar{a} d h)$ them, ${ }^{157}$ the mind that rests in its own [original] nature (svasvabhāva) provides the [moral] faults with no support/resting-place (āśraya) anymore (na punar), because its nature exists by force of [real] entities (vastubalapravrtta)." 158 As Devendrabuddhi has it, the mind or cognition now abides in its own proper and undefiled nature, which is nothing other than the grasping of the real aspects of the object projected onto it. The practice of the path, i.e.,

153 According to PVP D89a7-b1/P103a5: bdag med pa mthon ba goms pa grub pa na de ‘i ran bźin lam de’i bdag ñid can gyi sems la (*nairātmyadarśanābhyāsaniṣpattau tanmaye mārgasātmani citte).

${ }^{154}$ PVP D87a7-87b2/P100b2-5: lam goms pa la gnas pa'i sems la ñes pa rnams yan் 'byun ba'i nus pa yod pa ma yin no* || de ltar na sems kyi rañ bźin ni de kho na ñid mthon ba'i bdag ñid can yin gyi $\mid$ phyin ci log gi rnam pa dañ rjes su 'brel pa'i ñes pa de'i bdag ñid can ni ma yin no \| 'di'i ñe ba'i ñon mońs pa gá் yin pa de yan glo bur ba'i rkyen gyi dban gis yin no $\|$ de la gnod pa yod na ran gi ran bźin la gnas pa'i sems ni yañ ñes pa'i rten byed pa ma yin te |dnos po'i stobs kyis źugs pa'i ran bźin ñid yin pa'i phyir ro $\|$. *Cf. PVV 82,1-2: mārgasātmye 'pi sthitasya cetasi na doșānām utpattum sāmarthyam asti $\mid$.

155 PVT $\tilde{N}$ e D133a3-4/P164a2-3 explains tattvadarśanātmaka as follows: dìos po ji lta ba bźin du gnas pa'i 'dzin pa'i bdag ñid can (*yathāvasthitavastugrahaṇātmaka < PVV 82,14-15).

156 PVT $\tilde{N} e$ D133a5/P164a4-5 explains āgantu(ka)pratyaya as follows: rgyu mtshan 'ga' źig las bdag la sogs par sgro btags pas 'jug pa'i 'khrul pa'i śes pa.

157 PVT $\tilde{N}$ e D133a5-6/P164a5-6: de la gnod pa yod na źes bya ba glo bur ba'i rnam pas $\mid$ de'i rgyu can gyi ñe ba'i ñon mons pa bdag med pa'i lam gyis bsal ba yod na zes bya ba'i don to $\|$.

158 PVT $\tilde{N}$ e D133a6-7/P164a7-8: dnos po stobs kyis źugs pa'i rañ bźin ñid yin pa'i phyir ro źes bya ba ni dnos po ji ltar gnas pa bźin du 'dzin pas źugs pa'i bdag med pa'i lam ni sems kyi rañ bźin ñid yin pa'i phyir ro $\|$ (*yathāvasthitavastugrahanapravrttasya nairātmyamārgasya cittasvabhāvatvāt). 
cultivation, has freed the cognition of the obstacles that avidya was ultimately responsible for; in other words the mind is now free from the obstacle that concealed the knowable. Of the real and pramana-ascertained aspects the object imposes upon it, which are the real aspects of the four Noble Truths, the mind can have but a vivid and hence nonconceptual image. In other words: whereas the cintāmay $\bar{\imath}$ prajñ $\bar{a}$, i.e., the (initially purely conceptual) ascertainment of true reality by means of pramānas, is responsible for the reliability of the yogin's cognition, the bhävanāmaȳ prajñ $\bar{a}$ gradually frees the mind of the defilements in such a way that the aspects objects cast upon it appear vividly. Irrespective of all subsequent interpretations of the yoginām jūannam, this in my opinion is what Dharmakirti has in mind when he rather cryptically describes the cognition of yogins.

I would like to add a final remark. As far as I know, Dharmakirti does not describe the nature of discernment during the path itself, i.e., before the aśrayaparivrtti takes place. Now it is clear that, before entering the path of vision, the yogin has but an inferential and hence conceptual notion of such real aspects as impermanence, emptiness and the like. I would incline towards considering that his cognition of them remains a conceptual one, albeit extremely refined and hence vivid, throughout the path. But we ought not to forget that the mind is a purely momentary entity: the cognition that the path or the cultivation generates again and again may well be nothing like the cognition of the liberated one. This is exactly what the following stanzas of the $\mathrm{Pa}$ ramārthagāthās account for ${ }^{159}$ : “39. Defiled mind, of course (hi), is [something] that arises and ceases each time together with the Defilements. For it, liberation from the Defilements has [therefore] neither [already] happened nor will it [ever] happen. 40. [For it is] not that this [very same defiled mind] arises afterwards as a pure one, but [rather what] arises [afterwards is] another [mind which is pure]. And [it is]

159 Paramārthagāthā 39-41: sahotpannaniruddham hi kleśaị̣ kliștạn manaḥ sadā kleśebhyas tasya nirmokșo na bhūto na bhavișati || na tad utpadyate paścāc chuddham anyat tu jāyate | tac ca pūrvam asaṃkliștam klésebhyo muktam ucyate || yat kliṣtạ̣ tad ihātyantāc chuddham prakrtibhāsvaram |na ceha śudhyate kaścit kutaścid vāpi śudhyate $\|$. Text and translation in Schmithausen 1987: I.232-233 (see also the commentary on the stanzas in Schmithausen 1987: I.161-162). See also the Vaibhāṣika's account of liberation (vimukti) in AKBh 388,19-389,4, and Eltschinger 2005b: 190-192. 
this [other mind that, although it had] not [been] defiled before, is called 'liberated' from Defilements. 42. That which is defiled is, in this [system], absolutely [defiled]; [what is] pure is radiant by nature. And [thus (?) there is], in this [system], no [person or even dharma which] is purified, nor is [he/it, a fortiori,] purified from anything."

\section{ABBREVIATIONS AND BIBLIOGRAPHY}

AK(Bh) Prahlad Pradhan: Abhidharmakośabhāsyam of Vasubandhu. Patna, 1975: K.P. Jayaswal Research Institute (Tibetan Sanskrit Works Series, 8).

AKVy Unrai Wogihara: Sphuțārthā Abhidharmakośavyākhyā, the Work of Yaśomitra. Tokyo, 1989 (19361): Sankibo Buddhist Book Store (The Publishing Association of Abhidharmakośavyākhyā).

ASBh

Nathmal Tatia: Abhidharmasamuccayabhāsyam. Patna, 1976: K.P. Jayaswal Research Institute (Tibetan Sanskrit Works Series, 17).

BhK I First Bhāvanākrama (Kamalaśîla). Pp. 497/187-539/229 of Giuseppe Tucci: Minor Buddhist Texts. Delhi, 1986: Motilal Banarsidass.

BhK III Third Bhāvanākrama (Kamalaśîla). Giuseppe Tucci: Minor Buddhist Texts, Part III: Third Bhāvanākrama. Roma, 1971: Istituto Italiano per il Medio ed Estremo Oriente (Serie Orientale Roma, 43).

Bhsd $\quad$ Franklin Edgerton: Buddhist Hybrid Sanskrit Grammar and Dictionary. Volume II: Dictionary. Delhi, 1970: Motilal Banarsidass (New Haven, 1953: Yale University Press).

BoBh $\quad \mathrm{D}=$ Nalinaksha Dutt: Bodhisattvabhümih $[$ Being the XVth Section of Asañgapāda's Yogācārabhümih]. Patna, 1978: K.P. Jayaswal Research Institute (Tibetan Sanskrit Works Series, 7).

$\mathrm{W}=$ Unrai Wogihara: Bodhisattvabhumi. A Statement of Whole Course of the Bodhisattva (Being Fifteenth Section of Yogācārabhümi). Tokyo, 1971: Sankibo Buddhist Book Store.

$\mathrm{BoBh}_{\mathrm{t}}$ Cox 1995

$\mathrm{D}$

DBhS D n ${ }^{\circ} 4037$, Wi 1b1-213a7/P n5538, Źi 1b1-247a8.

Collett Cox: Disputed Dharmas. Early Buddhist Theories of Existence. An Annotated Translation of the Section on Factors Dissociated from Thought from Sañghabhadra's Nyāyānusāra. Tokyo, 1995: The International Institute of Buddhist Studies (Studia Philologica Buddhica, Monograph Series, 11).

Jikido Takasaki/Zuiho Yamaguchi/Noriaki Hakamaya: sDe dge Tibetan Tripitaka bsTan 'gyur preserved at the Faculty of Letters, University of Tokyo. Tokyo, 1977-1981.

Johannes Rahder: Daśabhūmikasūtra et Bodhisattvabhūmi, Chapitres Vihāra et Bhūmi. Paris/Louvain, 1926: Paul Geuthner/J.-B. Istas, Imprimeur (Société Belge d'Études Orientales). 
DhPr

Dreyfus 1997

Dunne 2006

Eltschinger 2005a

Eltschinger 2005b

Eltschinger 2007a

Eltschinger 2008

Franco 1989

Franco 1997

Franco 2001

senschaften

Eltschinger (forthcoming 1) = Vincent Eltschinger: "Studies in Dharmakīrti's Religious Philosophy: 4. The Cintāmaȳi Prajñā." To be published in Piotr Balcerowicz: Logic and Belief in Indian Philosophy. Delhi, 2008: Motilal Banarsidass (Warsaw Indological Studies, 3).

Eli Franco: "Was the Buddha a Buddha?" Journal of Indian Philosophy 17, pp. 81-99.

Eli Franco: Dharmakīti on Compassion and Rebirth. Vienna: Arbeitskreis für tibetische und buddhistische Studien Universität Wien (Wiener Studien zur Tibetologie und Buddhismuskunde, 38).

Eli Franco: "Dharmakīrti's Reductionism in Religion and Logic." Pp. 285-308 of Raffaele Torella: Le parole e $i$ marmi. Studi in onore di Raniero Gnoli nel suo $70^{\circ}$ compleano. Vol 1. Roma: Istituto Italiano per l'Africa e l'Oriente (Studie Orientale Roma, 92.1).

Franco forthcoming Eli Franco: "Perception of Yogis-Some epistemological and metaphysical considerations." To be published in Eli Franco/Helmut Krasser/Horst Lasic/Birgit Kellner: Proceedings of the Fourth Dharmakìrti Conference (Vienna, August 2005). Vienna: Verlag der Österreichischen Akademie der Wissenschaften. 
Hattori 1968

Jaini 2001

Jñānaprasthāna Kośa

Kritzer 2005

Lamotte 1935

Lamotte 1973

Lamotte 1974

Lamotte 1976

Lamotte 1987a

Lamotte $1987 b$

LAV

Mahāvibhāsā

Maithrimurthi 1999
Masaaki Hattori: Dignāga, On Perception, being the Pratyaksapariccheda of Dignāga's Pramānasamuccaya. Cambridge, Mass.: Harvard University Press (Harvard Oriental Series, 47).

Padmanabh S. Jaini: Collected Papers on Buddhist Studies. Delhi, 2001: Motilal Banarsidass.

T26 (1544).

Louis de La Vallée Poussin: L'Abhidharmakośa de Vasubandhu. 6 Vol. Bruxelles, 1980: Institut Belge des Hautes Études Chinoises (Mélanges Chinois et Bouddhiques, 16).

Robert Kritzer: Vasubandhu and the Yogācārabhümi. Yogācāra Elements in the Abhidharmakośabhāsya. Tokyo, 2005: The International Institute for Buddhist Studies (Studia Philologica Buddhica, Monograph Series, 18).

Étienne Lamotte: Saṃdhinirmocana Sūtra, l'explication des mystères. Louvain/Paris, 1935: Université de Louvain.

Étienne Lamotte: La Somme du Grand Véhicule d'Asanga (Mahāyānasangraha). 2 vol. Louvain-la-Neuve, 1973: Université de Louvain, Institut Orientaliste (Publications de l'IOL, 8).

Étienne Lamotte: "Passions and Impregnations of the Passions in Buddhism." Pp. 91-104 of L. Cousins/A. Kunst/K.R. Norman: Buddhist Studies in Honour of I.B. Horner. Dordrecht/Boston, 1974: D. Reidel Publishing Company.

Étienne Lamotte: Histoire du bouddhisme indien. Des origines à l'ère Śaka. Louvain-la-Neuve, 1976: Université de Louvain, Institut Orientaliste (Publications de l'IOL, 14).

Étienne Lamotte: L'enseignement de Vimalakīrti (Vimalakīrtinirdeśa). Louvain-la-Neuve, 1987: Université de Louvain, Institut Orientaliste (Publications de l'IOL, 35).

Étienne Lamotte: "Le troisième Bhāvanā-krama de Kamalaśīla. Traduction de la version tibétaine." Pp. 336-353 of Paul Demiéville: Le Concile de Lhasa, une controverse sur le quiétisme entre bouddhistes de l'Inde et de la Chine au VIII siècle de l'ère chrétienne. Paris, 1987: Collège de France, Institut des Hautes Études Chinoises (Publication de l'Institut des Hautes Études Chinoises, 7).

Bunyiu Nanjio: The Lankāvatāra Sütra. Kyoto, 1923: The Otani University Press (Bibliotheca Otaniensis, 1). T27 (1545).

Mudagamuwe Maithrimurthi: Wohlwollen, Mitleid, Freude und Gleichmut. Eine ideengeschichtliche Untersuchung der vier apramānas in der buddhistischen Ethik und Spiritualität von den Anfängen bis hin zum frühen Yogācāra. Stuttgart, 1999: Franz Steiner Verlag (Alt- und Neu-Indische Studien herausgegeben vom Institut für Kultur und Geschichte Indiens und Tibets an der Universität Hamburg, 50). 
McClintock 2002

McDermott 1991

MS

$\operatorname{MSA}(\mathrm{Bh})$

MSAVBh

Nagao 2000

$\mathrm{NB}(\mathrm{T})$

M

Nyāyānusāra

$\mathrm{P}$

Pemwieser 1991

Pruden 1991

$\mathrm{PS}(\mathrm{V})$

PST

PV 1-4
Sara McClintock: Omniscience and the Rhetoric of Reason in the Tattvasamgraha and the Tattvasamgrahapañjikā. Unpublished PhD Thesis. Cambridge, Massachusetts: Harvard University.

Charlene McDermott: "Yogic Direct Awareness as Means of Valid Cognition in Dharmakīrti and Rgyal-tshab." Pp. 144-166 of Minoru Kiyota: Mahāyāna Buddhist Meditation. Theory and Practice. Dehli, 1991: Motilal Banarsidass.

See Lamotte 1973: I.

Sylvain Lévi: Asañga. Mahāyāna-Sūtrālañkāra, Exposé de la doctrine du Grand Véhicule selon le système Yogācāra. Tome 1: texte. Paris, 1907: Librairie Honoré Champion.

Mahāyānasūtrālàikāravrttibhāṣya (Sthiramati). D n4034, Mi 1b1-Tsi 266a7.

Gadjin M. Nagao: “The Bodhisattva's Compassion Described in the Mahāyāna-sūtrālamkāra." Pp. 1-38 of Jonathan A. Silk: Wisdom, Compassion, and the Search for Understanding. The Buddhist Studies Legacy of Gadjin M. Nagao. Honolulu, 2000: University of Hawai'i Press (Studies in the Buddhist Traditions).

$\mathrm{S}=$ Th. I. Ščerbatskoj: Nyāyabindu. Buddijskij učebnik'” logiki sočinenie Dharmakirti I tolkovanie na nego Nyāyabinduț̄kā sočinenie Darmottary. Osnabrück, 1970 (Petrograd, 1918¹): Biblio Verlag (Bibliotheca Buddhica, 7).

Pandita Dalsukhbhai Malvania: Pandita Durveka Miśras's Dharmottarapradipa (Being a sub-commentary on Dharmottara's Nyāyabinduțīkā, a commentary on Dharmakīrti's Nyāyabindu. Patna, 1971: K.P. Jayaswal Research Institute (Tibetan Sanskrit Works Series, 2).

T29 (1562).

Daisetz T. Suzuki: The Tibetan Tripitaka, Peking Edition, Kept in the Library of the Otani University, Kyoto. Tokyo/Kyoto, 1957: Tibetan Tripitaka Research Institute.

Monika Pemwieser: Materialien zur Theorie der yogischen Erkenntnis im Buddhismus. Diplomarbeit zur Erlangung des magistergrades an der Universität Wien. Wien, 1991 (unpublished).

Leo M. Pruden: Abhidharmakośabhāsyam by Louis de La Vallée Poussin. English Translation by Leo M. Pruden. 4 vol. Berkeley, 1991: Asian Humanities Press.

Ernst Steinkellner: Pramānasamuccaya(vṛtti). Chapter I. www.oeaw.ac.at/ias/Mat/dignaga_PS_1.pdf. See also Hattori 1968.

Ernst Steinkellner/Helmut Krasser/Horst Lasic: Jinendrabuddhi's Viśālāmalavatī Pramānasamuccayațīā, Chapter 1. Part I: Critical Edition. Beijing/Vienna, 2005: China Tibetology Research Center/Austrian Academy of Sciences.

Yūsho Miyasaka: "Pramāṇavārttika-kārikā (Sanskrit and Tibetan)." Acta Indologica II (1971-1972), pp. 1-206. See also 
PVA

PVin 1

PVinT

PVP

PVSV

PVSVT

PVT

PVV

Rahder 1932

Schmithausen 1987

Schmithausen 2007

Seyfort Ruegg 1969

Siddhi

SNS
PVV; for PV 2-3, see also PVA; for PV 1, see also PVSV; for PV 2.131cd-285, see also Vetter 1990. My numerotation of the verses in PV 2 follows the one of Vetter.

Rāhula Sāṅkrtyāyana: Pramāṇavārttikabhāṣyam or Vārtikālañkārah of Prajñākaragupta (Being a Commentary on Dharmakīrti's Pramānavārtikam). Patna, 1953: K.P. Jayaswal Research Institute.

Ernst Steinkellner: Dharmakīrti's Pramānaviniścaya, Chapters 1 and 2. Beijing/Vienna, 2007: China Tibetology Publishing House/Austrian Academy of Sciences Press (Sanskrit Texts from the Tibetan Autonomous Region, 2).

Pramānaviniścayațīkā (Dharmottara). D n4229, Dze 1b1-Tshe 178a3/P n5727, Dze 1b1-We 209b8.

Pramānavārttikapañjikā (Devendrabuddhi). D n4217, Che 1326b4/P n ${ }^{\circ} 5717$, Che 1-390a8.

Raniero Gnoli: The Pramānavārttikam of Dharmakīrti. The First Chapter with the Auto-Commentary. Roma, 1960: Istituto Italiano per il Medio ed Estremo Oriente (Serie Orientale Roma, 23).

Rāhula Sānkṛtyāyana: Karnakagomin's Commentary on the Pramānavārttikavrtti of Dharmakīrti. Kyoto, 1982: Rinsen Books Co. (Allahabad, 1943: Kitab Mahal).

Pramānavārttikațīkā (Śākyabuddhi). $\mathrm{D} \quad \mathrm{n}^{\circ} 4220, \quad J e$ 1b1-Ñe 282a7/P n ${ }^{\circ} 5718$, Je 1b1- Ne 348a8.

Rāhula Sānkṛtyāyana: "Dharmakīrti’s Pramāṇavārttika with Commentary by Manorathanandin." Published as an appendix of the Journal of the Bihar and Orissa Research Society 24-26 (1938-1940).

Johannes Rahder: "La Satkāyadṛști d'après Vibhāṣā, 8." Mélanges Chinois et Bouddhiques 1 (1931-1932), pp. 227-239.

Lambert Schmithausen: Ālayavijñanna. On the Origin and the Early Development of a Central Concept of Yogācāra Philosophy. 2 volumes. Tokyo, 1987: The International Institute for Buddhist Studies (Studia Philologica Buddhica, Monograph Series, IVa/b).

Lambert Schmithausen: "Aspects of Spiritual Practice in Early Yogācāra." Journal of the International College for Postgraduate Buddhist Studies 11, pp. 213(/98)-244(/67).

David Seyfort Ruegg: La théorie du Tathāgatagarbha et du Gotra. Paris, 1969: École Française d'Extrême-Orient (Publications de l'École Française d'Extrême-Orient, Université de Paris, Faculté des Lettres et Sciences humaines).

Louis de La Vallée Poussin: Vijñaptimātratāsiddhi. La Siddhi de Hiuan-Tsang. 2 volumes. Paris, 1929: Librairie Orientaliste Paul Geuthner (Buddhica, Documents et travaux pour l'étude du bouddhisme publiés sous la direction de Jean Przyluski, Première série: Mémoires, 5).

Samihinirmocanasūtra. See Lamotte 1935. 
Steinkellner 1978 Ernst Steinkellner: "Yogische Erkenntnis als Problem im Buddhismus. Pp. 121-134 of Gerhard Oberhammer: Transzendenzerfahrung, Vollzugshorizont des Heils. Das Problem in indischer und christlicher Tradition. Arbeitsdokumentation eines Symposiums." Wien, 1978: Publications of the de Nobili Research Library, 5.

Steinkellner 1979 Ernst Steinkellner: Dharmakīrti's Pramānaviniścayah. Zweites Kapitel: Svārthānumānam. Teil II: Übersetzung und Anmerkungen. Wien, 1979: Verlag der Österreichischen Akademie der Wissenschaften (Veröffentlichungen der Kommission für Sprachen und Kulturen Südasiens, 15).

Suzuki 1999 Daisetz Teitaro Suzuki: Studies in the Lankāvatāra Sūtra. Delhi, 1999 (London, 19301): Motilal Banarsidass (Buddhist Tradition Series, 41).

$\mathrm{T}$

Junjirō Takakusu/Kaikyoku Watanabe: Taishō shinshū daizōkyō. Tōkyō, 1924-1932: Taishō Issaikyō Kankōkai.

Traité

Étienne Lamotte: Le Traité de la Grande Vertu de Sagesse de Nāgārjuna (Mahāprajūāpāramitāśāstra). 5 volumes. Louvain-laNeuve, 1981², 1981², 1970, 1976, 1980): Université de Louvain, Institut Orientaliste (Publications de 1'Institut Orientaliste, 25, 26, $2,12,24)$.

Tṛ̂h Triṃśikāvijñaptibhāṣya (Sthiramati). Sylvain Lévi: Vijñaptimātratāsiddhi, deux traités de Vasubandhu: Vimśatikā et Trimsíikā. Paris, 1925: Librairie Ancienne Honoré Champion (Bibliothèque de l'École des Hautes Études, Sciences historiques et philologiques, 245).

TS(P) $\quad \mathrm{K}=$ Embar Krishnamacharya: Tattvasangraha of Śantaraksita With the Commentary of Kamalaśila. 2 vol. Baroda, 1984: Oriental Institute.

Ś = Swami Dwarikadas Shastri: Tattvasangraha of Ācārya Shāntarakșita with the Commentary 'Pañjikā' of Shri Kamalshīla. 2 vol. Varanasi, 1981: Bauddha Bharati (Bauddha Bharati Series, $1)$.

Vetter 1964

Tilmann Vetter: Erkenntnisprobleme bei Dharmakīti. Wien, 1964: Hermann Böhlaus Nachf., Kommissionsverlag der Österreichischen Akademie der Wissenschaften (Österreichische Akademie der Wissenschaften, philologisch-historische Klasse, Sitzungsberichte, 245).

Vetter 1990 Tilmann Vetter: Der Buddha und seine Lehre in Dharmakīrtis Pramānavārttika. Der Abschnitt über den Buddha und die vier edlen Wahrheiten im Pramānasiddhi-Kapitel. Wien, 1990: Arbeitskreis für tibetische und buddhistische Studien Universität Wien (Wiener Studien zur Tibetologie und Buddhismuskunde, 12).

Vibh. VinSg Vibhūticandra's notes to PVV. See PVV.

Viniścayasañgrahaṇ̄ of the Yogācārabhūmi. P n5539, Zi 1b1 ' $\mathrm{i} 142 \mathrm{~b} 8$. 
Wayman 1961

Alex Wayman: Analysis of the Śrāvakabhümi Manuscript. Berkeley/Los Angeles, 1961: University of California Press. 
